\title{
Amelia Greenwald i Szkoła Pielęgniarstwa przy Szpitalu Starozakonnych na Czystem w Warszawie
}

\author{
Amelia Greenwald and the Nursing School at the Old \\ Jewish Hospital at Czyste in Warsaw
}

\section{Summary}

The American nurse Amelia Greenwald was the creator and first director of the Jewish School of Nursing at the Old Jewish Hospital in Warsaw. During World War I she served in the American Expeditionary Corps fighting in Europe and was a member of the American Red Cross. In 1923, Greenwald received a proposal to create and run one of the most modern educational institutions training nurses in Warsaw, Poland. The school was founded thanks to the efforts of the AmericanJewish Medical Affairs Committee of the Joint Distribution Committee, also known as Joint and the Society for Supporting the School of Nurses at the Old Jewish Hospital in Warsaw. The history of the school created by Greenwald has already been described by Zofia Podgórka-Klawe and Iwona Kowalkowska. The first of them outlined the functioning of the institution based on the prospectus of the School of Nursing developed in 1928 by the then director Sabina Schindlerówna. The second author also reviewed the medical press and described the wartime period of the school and the fate of its graduates. This article focuses on the character of the first headmistress of the School and her work on establishing the institution. As the main source base, documents collected in the Archives of the American Jewish Joint Distribution Committee (JDC Archives) were used and made available on the website https://archives.jdc.org. The author has translated some documents from English to Polish to present the history of the Nursing School at the Old Jewish Hospital in Warsaw. 
Slowa kluczowe: Amelia Greenwald, Szkoła Pielęgniarstwa przy szpitalu Starozakonnych w Warszawie

Keywords: Amelia Greenwald, Nursing School at the Old Jewish Hospital at Czyste in Warsaw

Kim była tajemnicza Amelia Greenwald, pierwsza kobieta odznaczona Krzyżem Zasługi za stworzenie Szkoły Pielęgniarstwa przy Szpitalu Starozakonnych na Czystem? Jak wiele osób wie, że prócz zasług w materii medycznej to właśnie ona upowszechniła w Polsce picie schłodzonej herbaty, nazywanej ice-tea? ${ }^{1}$ A może ktoś słyszał o tym, że prezydent Ignacy Mościcki osobiście prosił ją, aby pozostała w Polsce? Zapewne nie, a szkoda, bo Amelia Greenwald na wiele lat zapisała się w pamięci uczennic jako osoba przywracająca innym kobietom dumę z faktu, że są dobrze wykształcone i potrzebne oraz że uprzedzenia narodowościowe muszą ustąpić sile kobiecego profesjonalizmu.

Amelia Greenwald urodziła się 1 marca 1881 r. w miejscowości Gainesville, w stanie Alabama. Była jednym z ośmiorga dzieci niemieckich imigrantów Josepha Greenwalda i Elizy Haas. Już jako mała dziewczynka postanowiła zostać wykształconą pielęgniarką, gdy siedząc na kolanach ojca, słuchała opowieści na temat wojny secesyjnej. Rodzice byli jednak innego zdania. Mimo ich sprzeciwu Amelia rozpoczęła szkolenie pielęgniarskie w Touro Infirmary Training School for Nurses, TISON w Nowym Orleanie ${ }^{2}$. Dyplom ukończenia szkoły uzyskała w 1908 r. Rok później zaangażowała się w tworzenie szpitala w mieście Pensacola na Florydzie. Inicjatorem przedsięwzięcia był dr Charles E. Hutchinson. Przełożoną pielęgniarek została panna Dewitt Dillard, o rok starsza od Amelii absolwentka szkoły w Touro ${ }^{3}$, ponieważ jednak z opóźnieniem dotarła do Pensacoli, jej obowiązki przejęła i wypełniła Greenwald. Nowy szpital opisywano jako nowoczesną placówkę, oferującą dwadzieścia miejsc dla chorych. Wyposażony był w aparat do wykonywania zdjęć rentgenowskich oraz laboratorium analityczne. Znajdowała się tam także sala zabiegowa oraz pełne zaplecze gospodarcze ${ }^{4}$. Posiadał nawet windę. Za budynkiem

\footnotetext{
1 S. Mayer, Amelia Greenwald and Regina Kaplan: Jewish Nursing Pioneers, „Southern Jewish History” 1998, s. 89.

${ }^{2}$ Taż, Amelia Greenwald (1881-1966), [w:] V.L. Bullough, L. Sentz (red.), American Nursing: A Biographical Dictionary, t. 3, New York 2000, s. 109.

${ }^{3}$ Taż, Amelia Greenwald and Regina Kaplan..., dz. cyt., s. 85.

${ }^{4}$ Pensacola Sanitarium Opens Its Doors, „Pensacola Journal” 1909, nr z 15 stycznia, s. 1. Tekst dostępny jest online: https://www.pensapedia.com/wiki/Pensacola_Sanitarium [dostęp: 2.03.2020].
} 
głównym wzniesiono połączoną z nim salę operacyjną wraz z urządzeniami sterylizacyjnymi. Przy szpitalu działała szkoła dla pielęgniarek prowadzona przez zarządcę oraz dwie dyplomowane pielęgniarki.

Po zakończeniu prac organizacyjnych Amelia Greenwald przeniosła się do pracy w szpitalu w Karolinie Północnej. W 1913 r. przeprowadziła się do Baltimore, aby ukończyć kurs pielęgniarstwa psychiatrycznego w Phipps Clinic na Uniwersytecie Johna Hopkinsa (ang. John Hopkins University). W tym czasie poznała Henriettę Szold, która wprowadziła ją w idee syjonizmu i zachęcała do wyjazdu do Palestyny $^{5}$. Prawdopodobnie pod jej wpływem Amelia Greenwald wróciła do Nowego Yorku, aby wziąć lekcje języka hebrajskiego i jidysz oraz uzupełnić wiedzę z zakresu historii Żydów. W tym samym czasie uczęszczała na zajęcia pielęgniarstwa społecznego w Szkole Pielęgniarstwa przy Uniwersytecie Columbia (Columbia University Teachers College). Po ukończeniu kursu zdecydowała się jednak na prace dla firmy ubezpieczeniowej Metropolitan Life Insurance Company i kierowała najstarszym, bo założonym w 1875 r. stowarzyszeniem zajmującym się problemami zdrowia publicznego w New Jersey (New Jersey Public Health Association). Pomagała także Lillian Wald prowadzącej organizację wspierającą imigrantów mieszkających na nowojorskim Manhattanie w Schronisku przy Henry Street (Henry Street Settlement) ${ }^{6}$. W trakcie epidemii polio była jedną $\mathrm{z}$ wielu pielęgniarek odwiedzających chorych w ich domach ${ }^{7}$.

W czasie I wojny światowej służyła jako pielęgniarka w walczącym w Europie Amerykańskim Korpusie Ekspedycyjnym (American Expeditionary Forces, AEF). Była też członkinią Amerykańskiego Czerwonego Krzyża (American Red Cross, numer odznaki 5532). Stacjonowała we Francji, gdzie m.in. pełniła funkcję głównej pielęgniarki w szpitalu polowym w trakcie bitwy pod Verdun, opiekując się żołnierzami,

${ }^{5}$ S. Mayer, Amelia Greenwald and Regina Kaplan..., dz. cyt., s. 86. Autorka powołuje się na następujące źródło: L. Sokoloff, Amelia Greenwald (1881-1966). Pioneer American-Jewish Nurse, „Korot” 1993-1994, s. 92-101.

${ }^{6}$ Lillian Wald (1867-1940) założyła w 1893 r. instytucję opiekuńczą, która wspierała ubogie środowisko imigrantów na Manhattanie (Nurses' Settlement, dwa lata później zmieniono nazwę na Henry Street Settlement). Jedną z form pomocy była opieka świadczona przez pielęgniarki środowiskowo-społeczne zarówno w domach prywatnych, jak i w szkołach publicznych. Lillian Wald wspierała także finansowo Narodową Organizację Pielęgniarstwa Społecznego i Szkołę Pielęgniarstwa przy Uniwersytecie Columbia. Więcej informacji na ten temat czytelnik znajdzie na stronie internetowej: https://www.henrystreet.org/about/our-history/lillian-wald/.

${ }^{7}$ Pielęgniarki nosiły specjalne torby według projektu Lillian Wald, tzw. H.S.S. Visiting Nurse Bag. Taką torbę A. Greenwald otrzymała od samej L. Wald, gdy wyjeżdżała do Polski. 
którzy cierpieli na zespół stresu bojowego (shell shock) - reakcję niektórych żołnierzy na traumę spowodowaną działaniami wojskowymi, takimi jak bombardowania czy intensywny ostrzał artyleryjski. Objawy stresu bojowego mogły, poza olbrzymim lękiem, powodować także niezdolność do mówienia czy nawet poruszania się. Z Verdun skierowano ją do pracy w podlegającym AEF szpitalu w Savoy. Przed powrotem do Stanów Zjednoczonych zdążyła jeszcze pomóc w założeniu pierwszego amerykańskiego szpitala w Koblencji. Opiekowała się także amerykańskimi wdowami wojennymi. Za swoją służbę w sektorze obronnym Meuse-Argonne otrzymała Medal Zwycięstwa. Przez całe życie utrzymywała członkostwo w Legionie Amerykańskim (American Legion).

W 1919 r. Amelia Greenwald została poproszona przez Narodowa Radę Kobiet Żydowskich (National Council of Jewish Women), by współtworzyć i kierować programem wspomagającym żydowskie rodziny, które chciałyby osiedlać się poza wielkimi miastami ${ }^{8}$. Podjęła $\mathrm{i}$ to wyzwanie, rozpoczynając pracę $\mathrm{w}$ Woodridge, małym miasteczku w stanie Nowy York ${ }^{9}$. Dwa razy w tygodniu udzielała lekcji języka angielskiego, zajmowała się pielęgniarstwem środowiskowo-społecznym oraz stworzyła program propagujący zasady higieny przeznaczony dla szkół publicznych. Współtworzyła także bibliotekę z książkami w języku jidysz, rosyjskim i angielskim. Mimo że rodzice Amelii byli żydowskimi imigrantami z Niemiec, ona sama nie mówiła w języku jidysz. W 1923 r. otrzymała propozycję utworzenia i prowadzenia Szkoły Pielęgniarstwa przy Szpitalu Starozakonnych w Warszawie, jednej z najnowocześniejszych placówek tego typu w Polsce. Osobą bezpośrednio namawiającą ją do podjęcia współpracy był Bernard Flexner, ówczesny przewodniczący Komitetu Spraw Medycznych (Committee on Medical Affairs) Amerykańsko-Żydowskiego Połączonego Komitetu Rozdzielczego, nazywanego też w skrócie Jointem (American Jewish Joint Distribution Committee, AJJDC). Organizacja ta powstała $\mathrm{w} 1914 \mathrm{r}$. z inicjatywy elitarnej organizacji o charakterze syjonistycznym American Jewish Committee (AJC), aby dystrybuować środki pieniężne zebrane przez organizacje charytatywne: American Jewish Relief Committee, ortodoksyjny Central Relief Committee i ro-

\footnotetext{
${ }^{8}$ Narodowa Rada Kobiet Żydowskich (National Council of Jewish Women), organizacja założona w 1893 r. przez Hannę Salomon w celu promocji religii mojżeszowej i ochrony dziedzictwa kulturowego Żydów. W 1904 r. Rada przekształciła się w Międzynarodową Radę Żydowskich Kobiet. F. Rogow, National Council of Jewish Women, https://jwa.org/encyclopedia/article/national-council-of-jewish-women [dostęp: 2.03.2020].
}

${ }^{9}$ S. Mayer, Amelia Greenwald (1881-1966)..., dz. cyt., s. 110. 
botniczy People's Relief Committee (stąd określenie joint - łączny). W Polsce Joint prowadził początkowo akcję pomocy ofiarom wojny. Biuro agencji mieściło się w Warszawie przy ul. Nalewki $2 \mathrm{a}^{10}$. Bieda skutkująca niedożywieniem i niskim poziomem higieny była bezpośrednio związana $\mathrm{z}$ epidemiami tyfusu plamistego, tyfusu brzusznego, strupnia i innych chorób zakaźnych. Dystrybucja żywności, bielizny, mydła i leków prowadzona przez Joint była określana jako pomoc bezpośrednia. W $1921 \mathrm{r}$. Joint przystąpił do akcji rekonstrukcyjnej ${ }^{11}$. $\mathrm{W}$ ramach tzw. rekonstrukcji funkcjonalnej wspierał m.in. finansowo działalność Towarzystwa Ochrony Zdrowia Ludności Żydowskiej (TOZ), jak i Centrali Towarzystw Opieki nad Sierotami i Dziećmi Opuszczonymi (Centos), a także wielu innych instytucji żydowskich ${ }^{12}$. Inżynier Adam Czerniaków - działacz gospodarczy, oświatowy i społeczny - był zdania, że właśnie taki rodzaj pomocy sprawia, że polscy Żydzi nie czują się traktowani jako biorcy otrzymujący dobroczynną pomoc, lecz ludzie o równych prawach ${ }^{13}$. Głównym założeniem kampanii pomocowej prowadzonej przez utworzoną w tym celu organizację American Jewish Reconstruction Fund (AJRF) była mobilizacja społeczności żydowskiej i stopniowe przejmowanie przez nią kontroli nad utworzonymi bądź wspieranymi instytucjami.

Równocześnie z prowadzeniem szeroko zakrojonej akcji pomocowej przedstawiciele władz Jointu bezpośrednio zaangażowani $\mathrm{w}$ to przedsięwzięcie chcieli, aby powstająca szkoła niosła ze sobą nowoczesne przesłanie, w myśl którego młode, żydowskie dziewczęta mogłyby się włączać w działalność służb państwowych (national service), ucząc się „diagnozować i leczyć nie tylko fizyczne, ale także poważniejszego rodzaju rany"14. Tym samym wierzono, że medyczny

${ }^{10}$ List ministra spraw wewnętrznych Władysława Kiernika z dnia 27 września 1923 r. do biura AJDC w Warszawie, dotyczący likwidacji biura Jointu w Polsce. JDC Archives NY AR191232/4/25/3/0309.

${ }^{11}$ Z. Szajkowski, „Reconstruction” vs. „Palliative Relief” In American Jewish Overseas Work (1919-1939), „Jewish Social Studies” 1970, t. 32, nr 1, s. 14-15. Szajkowski dzieli okresy pomocy na: okres pomocy bezpośredniej (1914-1918), okres rozbrojenia i pomocy doraźnej (1919-1920), okres rekonstrukcji funkcjonalnej (1921-1925) i okres systematycznej odbudowy i regulacji (od $1925 \mathrm{r}$ ).

12 Szerzej na temat działalności TOZ-u w Polsce: M. Ciesielska, Działalność Towarzystwa Ochrony Zdrowia Ludności Żydowskiej w Polsce (TOZ) ze szczególnym uwzględnieniem Kresów Wschodnich w okresie dwudziestolecia międzywojennego $w$ świetle dostępnych dokumentów, [w:] B. Urbanek (red.), Medycy polskiego pogranicza II Rzeczypospolitej 1918-1939, Warszawa 2018, s. 327-351.

${ }^{13}$ Z. Szajkowski, dz. cyt., s. 26.

14 D.K. Heller, The Gendered Politics of Public Health: Jewish Nurses and the American Joint Distribution Committee in Interwar Poland, „Jewish History” 2018, nr 31, s. 320. 
profesjonalizm połączony z etosem współpracy przyczyni się do zmiany nastawienia wobec Żydów w Europie. Greenwald, pełna entuzjazmu i idei zaczerpniętych od Lillian Wald, była doskonałą kandydatką na to stanowisko. Tuż przed wyjazdem do Europy napisała do Felixa M. Warburga, przewodniczącego AJJDC: „W trakcie dzisiejszej porannej rozmowy telefonicznej otrzymałam olbrzymią zachętę i inspirację, i pragnę, aby Pan wiedział, że jadę do Europy zdeterminowana zrobić wszystko, co w mojej mocy, aby położyć podwaliny pod pracę, która - mam nadzieję - będzie tym dla Europy, czym Henry Street Settelment jest dla Ameryki”" ${ }^{15}$. Wierzyła też głęboko, że „wyszkolone przez nią pielęgniarki przyczynią się do złagodzenia uprzedzeń i będą lepszym źródłem wzajemnego zrozumienia pomiędzy Żydami i nieŻydami niż jakakolwiek instytucja w kraju"16. Sytuacja, jaką zastała na miejscu, kazała jej zweryfikować swoje poglądy. Wykształcenie oddanych Polsce pielęgniarek nie było łatwym zadaniem. Pochodzące z Kresów Wschodnich, ale także ze stolicy dziewczęta doświadczały różnych przejawów antysemityzmu z pogromami włącznie.

\section{Żydowska Szkoła Pielęgniarstwa w Warszawie - początki}

Zanim Amelia Greenwald przyjechała do Warszawy, by utworzyć tu szkołę dla pielęgniarek, dziewczęta kształciły się w tym kierunku w ramach kursów organizowanych przez Żydowski Związek Kobiet oraz w szkole pielęgniarstwa dziecięcego przy Szpitalu Dziecięcym Bersohnów i Baumanów przy ul. Śliskiej w Warszawie ${ }^{17}$. Od 1921 r. działała także, kierowana przez dyplomowaną, amerykańską pielęgniarkę Helen Bridge ${ }^{18}$, Warszawska Szkoła Pielęgniarstwa (WSP), powstała

15 JDC Archives NY AR191232/4/25/3/0217. List A. Greenwald do F.M. Warburga datowany 19 stycznia $1923 \mathrm{r}$.

16 Tamże.

17 Szpital Bersohnów i Baumanów został zamknięty w 1923 r. na okres kilku lat. Obie instytucje wykształciły niewielką liczbę uczennic. Ponadto poza Warszawą funkcjonowała Poznańska Wyższa Szkoła Pielęgniarstwa PCK, Lwowska Szkoła Pielęgniarstwa oraz kursy pielęgniarskie przygotowujące do państwowego egzaminu pielęgniarskiego, które były organizowane m.in. przez krakowskich bonifratrów (Kraków, Katowice), a także kursy pielęgniarskie dla sióstr zakonnych przy Szpitalu św. Rocha (Warszawa). Szkoły pielęgniarstwa, Wirtualne Muzeum Pielęgniarstwa Polskiego (WMPP), http:// www.wmpp.org.pl/pl/szkoly-pielegniarskie.html [dostęp: 8.03.2020]. Według Zalashika i Davidovitcha w Polsce działała także szkoła w Łodzi. R. Zalashik, N. Davidovitch, The course of professionalization: Jewish nursing in Poland in the interwar period, „Science in Context" 2019, nr 32(1), s. 97.

18 Helen Bridge, podobnie jak Amelia Greenwald, ukończyła kurs w Szkole Pielęgniarstwa przy Uniwersytecie Columbia (Columbia University Teachers College). Podczas pobytu w Warszawie obie kobiety pomagały sobie wzajemnie i spotykały 
z inicjatywy Ignacego i Heleny Paderewskich oraz Henryka Sienkiewicza jako fundacja z prywatnych ofiar pieniężnych. Jej sponsorami byli: Dorothea Hughes - amerykańska pielęgniarka pochodzenia polskiego, Amerykański Czerwony Krzyż (American Red Cross, ARC), Fundacja Rockefellera, Polski Czerwony Krzyż (PCK), Ministerstwo Zdrowia i Wydział Lekarski Uniwersytetu Warszawskiego ${ }^{19}$. Do użytku szkoły PCK przeznaczył dwa pawilony na terenie szpitala przy ul. Smolnej 6. Meble i wyposażenie szkoły ofiarował ARC. W 1922 r. Fundacja Rockefellera ofiarowała na budowę gmachu 100000 dolarów, resztę uzupełnił rząd polski. Także zarząd miasta przyznał kredyt na wyposażenie nowej szkoły. W 1920 r. powołano radę administracyjną, w której skład weszli delegaci Ministerstwa Zdrowia Publicznego, Magistratu m.st. Warszawy, Wydziału Lekarskiego Uniwersytetu Warszawskiego, Polskiego Czerwonego Krzyża, a także dyrektorka szkoły reprezentująca ARC - Helen Bridge. Rada opracowała statut szkoły, zatwierdzony przez radę miejską 7 lipca $1921 \mathrm{r}$. Kandydatki, w wieku od 18 do 35 lat, musiały przedstawić świadectwo ukończenia co najmniej 6 klas gimnazjum albo tzw. małą maturę i zaświadczenie lekarskie o stanie zdrowia. Ponadto należało dostarczyć dwie opinie: „jedną od proboszcza parafii, w której mieszkała kandydatka, drugą ze szkoły średniej lub od osoby stojącej wysoko w hierarchii społecznej bądź naukowej" ${ }^{20}$. Z zachowanych dokumentów AJJDC wynika, że żydowskie, niemieckie i rosyjskie dziewczęta nie mogły ubiegać się o przyjęcie do szkoły ${ }^{21}$.

Odpowiedzią na faktyczne wprowadzenie zasady numerus nullus w Warszawskiej Szkole Pielęgniarstwa było powołanie przez dr Zofię (Sarę) Syrkin-Binsztejnową (Binsztajnową) lokalnego komitetu, który mógłby zwrócić się do Jointu z prośbą o dofinansowanie budowy szkoły pielęgniarskiej dla dziewcząt żydowskich ${ }^{22}$. Doktor Syrkin-

się prywatnie. JDC Archives NY AR/191232/4/25/0870. Maszynopis napisany przez A. Greenwald (bez daty, bez tytułu).

${ }_{19}$ H. Witkiewicz, Warszawska Szkoła Pielęgniarstwa, http://www.wmpp.org.pl/pl/ szkoly-pielegniarskie/szko\%C5\%82a-warszawska.html [dostęp: 3.03.2020].

20 M.B. Jezierska, Warszawska Szkoła Pielegniarstwa w latach 1929-1939, [w:] Pochylone nad człowiekiem. Z dziejów Warszawskiej Szkoły Pielęgniarstwa 1921-1945, Praca zbiorowa, Warszawa 1991, s. 99.

21 JDC Archives NY AR191232/4/25/3/0146. Memorandum Anny Bercowitz ze spotkania z H. Bridge, adresowane do Morrisa D. Waldmana, Departament Medyczno-Sanitarny AJJDC w Wiedniu, datowane na 17 stycznia 1922 r. NY AR191232/4/25/3/0149. List B. Flexnera do Josephine Goldmark datowany na 10 kwietnia 1922 r.

${ }^{22}$ Zofia Sara Syrkin-Binsztejnowa (1891-1943), lekarka, działaczka społeczna, od 1919 r. zaangażowana w kampanię zwalczania tyfusu plamistego w Zachodniej Galicji prowadzoną przy wsparciu Jointu, od 1921 r działaczka TOZ-u w Polsce, w getcie war- 
-Binsztejnowa opracowała też niezwłocznie wstępny plan nauczania, który jesienią 1921 r. przedstawiła działaczom AJJDC w Warszawie. Zaproponowane przez nią curriculum różniło się od eksperymentalnego systemu blokowego zastosowanego w Warszawskiej Szkole Pielęgniarstwa, w ramach którego uczennice na zmianę odbywały nauczanie teoretyczne i praktyczne. Plan szkolenia różnił się też istotnie od zamysłu Jacoba J. Goluba (1892-1953), dyrektora Departamentu Medyczno-Sanitarnego Jointu w Warszawie, młodego, amerykańskiego lekarza specjalizującego się w chorobach stawów, który zanim przybył do Warszawy, był członkiem misji medycznej na Wołyniu. Zorganizował tam w 1921 r. sześciomiesięczne kursy pielęgniarskie przy Szpitalu Żydowskim w Równem ${ }^{23}$. Jedynym powodem utworzenia tych szkoleń były względy praktyczne - brak personelu pomocniczego - nie zaś żadna konkretna idea ${ }^{24}$. Co więcej, dr Golub zdawał sobie sprawę, że kształcenie pielęgniarek może być opłacalne, jako że powszechnie kobietom wypłacano niższe pensje niż mężczyznom. Był zdania, że szkolenie pielęgniarek polega głównie na „przenoszeniu ich instynktów macierzyńskich i odpowiedzialności w sferę działań publicznych i nalegał, aby ich rola była okrojona i nadzorowana przez zdominowaną przez mężczyzn profesję lekarską"25. Miały się one stać kimś na kształt „ambasadorek higieny” uczących matki i dzieci podstaw higieny. Jakkolwiek wielu członków personelu medycznego Jointu w Polsce podzielało poglądy dr. Goluba, to sprzeciwiła się im, uczestnicząca w naradach komisji medycznej Jointu w Polsce (AJJDC Medical Comission), dr Zofia Syrkin-Binsztejnowa. Propozycję dr. Goluba nazwała „prymitywną i powierzchowną”, a swoim kolegom jasno zakomunikowała, że ,jeśli ci Amerykanie mają tu przyjechać, by pomóc polskim Żydom, to niech chociaż zostawią po sobie coś konkretnego i trwałego" ${ }^{26}$. Tym czymś, jej zdaniem, miały być szkoły pielęgniarskie w Warszawie, Wilnie i Krakowie ${ }^{27}$.

Curriculum przedstawione przez dr Syrkin-Binsztejnową miało klasyczny układ polegający na równoczesnym, trwającym dwa lata na-

szawskim przewodnicząca Rady Zdrowia przy Radzie Żydowskiej. J.D. Golden, “Show that you are really alive": Sara-Zofia Syrkin-Binsztejnowa's Emergency Medical Relief and Public Health Work in Early Interwar Poland and the Warsaw Ghetto, „Medizinhistorisches Journal” 2018, t. 53, z. 2, s. 125-162.

${ }^{23}$ Inni badacze podają, że kurs trwał dwa miesiące. R. Zalashik, N. Davidovitch, dz. cyt., s. 98.

${ }^{24}$ D.K. Heller, dz. cyt., s. 325.

${ }^{25}$ Tamże, s. 326.

${ }^{26}$ Tamże, s. 327.

${ }^{27}$ Szkoła Pielęgniarstwa w Wilnie powstała w maju 1922 r. pod auspicjami TOZ-u. 
uczaniu teorii i praktyki. Zanim jednak zostało zaakceptowane przez Joint, było szeroko konsultowane w kręgach eksperckich w Stanach Zjednoczonych. Trzy-, a nawet dwuletni okres nauczania był zdaniem części osób zbyt długi. Uważali, że szkoła utworzona w Warszawie powinna kształcić przyszłe instruktorki i liderki zdrowia publicznego w systemie dwuletnim, a szkoły w Wilnie, Krakowie czy Lwowie proponować roczne kursy dla pielęgniarek pracujących przy łóżku chorego $^{28}$. Niezależnie od czasu trwania nauki program został oceniony jako zgodny $\mathrm{z}$ amerykańskimi wytycznymi i bardzo dobrze przyjęty, choć Josephine Goldmark, odpowiedzialna za reformę nauczania pielęgniarstwa w Stanach Zjednoczonych, była zdecydowanie przeciwna skracaniu nauki do roku poza szczególnymi okolicznościami ${ }^{29}$. Obawiano się jedynie, jak nowa profesja pielęgniarki dyplomowanej zostanie przyjęta przez polskich lekarzy przyzwyczajonych do bezwzględnego posłuszeństwa ze strony personelu pomocniczego i patrzących z podejrzliwością na niezależne i pełne własnej inicjatywy pielęgniarki. Eksperci stanęli też na stanowisku, że błędem jest nauczanie pieleggniarstwa pediatrycznego (tak jak przez jakiś czas próbowała to wprowadzić naczelna lekarka Szpitala Bersohnów i Baumanów dr Anna Braude-Hellerowa), jako że wszelkie specjalizacje w dziedzinie pielęgniarstwa powinny być wprowadzane po ukończeniu szkolenia podstawowego. Według opinii i wstępnych planów zarząd szkoły powinien być całkowicie niezależny od któregokolwiek szpitala, jakkolwiek w skład zarządu powinni wchodzić dwaj przedstawiciele szpitala, w którym odbywać się miały ćwiczenia praktyczne. Szpital ten powinien mieć miejsca dla minimum 200 chorych, w tym poza oddziałami chorób wewnętrznych także oddział dziecięcy, chirurgiczny i położniczy. Eksperci zalecali, aby dbać o to, żeby dziewczęta nie były wykorzystywane do prac niezwiązanych z ich kształceniem. Zadaniem szkoły nie miało być bowiem dostarczenie brakującego personelu, ale szkolenie uczennic przy łóżku chorego. Kadra zarządzająca i dydaktyczna szkoły powinna składać się z dyrektorki i przynajmniej jednej asystentki, przy czym obie powinny pełnić też funkcję instruktorek. Oprócz nich w skład kadry winny wchodzić: dietetyczka i pielęgniarki sprawujące nadzór nad pielęgniarkami pracującymi w oddziałach szpitalnych. Pozostali wykładowcy powinni rekrutować się spośród lekarzy szpitalnych. Dziewczęta przyjęte do szkoły powinny cieszyć

${ }^{28}$ JDC Archives NY AR191232/4/25/3/0149. List B. Flexnera do J. Goldmark datowany na 10 kwietnia $1922 \mathrm{r}$.

29 JDC Archives NY AR191232/4/25/3/0158. Odpowiedź J. Goldmark na list B. Flexnera datowana na 15 kwietnia $1922 \mathrm{r}$. 
się dobrym zdrowiem, mieć średnie wykształcenie, dobry charakter i być w wieku około 20 lat. Internat, w którym miały zamieszkać, powinien być urządzony stosownie do potrzeb, wyżywienie dobre, a nad wszystkim powinna czuwać gospodyni domu. Co najważniejsze, wszyscy eksperci, jak i Flexner, byli zdania, że pierwszą dyrektorką szkoły powinna zostać dyplomowana, amerykańska pielęgniarka ${ }^{30}$.

W marcu 1922 r. Ministerstwo Spraw Wewnętrznych zatwierdziło statut Towarzystwa Popierania Szkoły Pielęgniarek (TPSP) przy Szpitalu Starozakonnych w Warszawie ${ }^{31}$. Celem działań TPSP było krzewienie racjonalnego pielęgniarstwa, kształcenie pielęgniarek i opieka nad nimi. Zadaniem Towarzystwa było:

1. Prowadzenie szkoły pielęgniarek $\mathrm{z}$ internatem,

2. Prowadzenie kursów uzupełniających dla pielęgniarek, które ukończyły szkołę,

3. Prowadzenie domu dla byłych uczennic szkoły,

4. Polecanie wykształconych pielęgniarek szpitalom, zakładom leczniczym, instytucjom higieniczno-lekarskim i chorym prywatnym,

5. Udzielanie pomocy chorym pielęgniarkom,

6. Organizowanie pielęgniarkom zabezpieczenia na wypadek niezdolności do pracy i starości.

Zgodnie ze statutem fundusze TPSP pochodzić miały ze składek członkowskich (składki płacili członkowie rzeczywiści), zapomóg ze strony państwa, zapomóg komunalnych, ofiar, darowizn i zapisów, jak i ze środków pozyskanych w trakcie kwest, odczytów, przedstawień i innych przedsięwzięć dochodowych ${ }^{32}$. Głównym darczyńcą został oczywiście Joint, jednak aby uniknąć sytuacji, jaka miała miejsce w utworzonej przez AJJDC szkole pielęgniarskiej w Jerozolimie, gdzie lokalna społeczność nie mogła wspomóc w żaden sposób jej działalności, od początku planowano stopniowe przejmowanie obowiązków związanych z prowadzeniem szkoły przez lokalne organizacje. Łączny koszt uruchomienia placówki i jej funkcjonowania przez pierwsze dwa lata (bez wydatków związanych z wynagrodzeniem dla instruktorek) szacowano zgodnie z wyliczeniami dr Syrkin-Binsztejnowej na 17 tys.

\footnotetext{
${ }^{30}$ JDC Archives NY AR191232/4/25/3/0149. List B. Flexnera do Josephine Goldmark datowany na 10 kwietnia 1922 r. Według danych ARC w 1921 r. w Polsce były jedynie cztery dyplomowane pielęgniarki, które odbyły szkolenia w Anglii lub we Włoszech. R. Zalashik, N. Davidovitch, dz. cyt., s. 97.

31 JDC Archives NY AR191232/4/25/3/0422. Statut Towarzystwa Popierania Szkoły Pielęgniarek przy Szpitalu Starozakonnych w Warszawie. Statut TPSP został zatwierdzony na zasadzie postanowienia Ministerstwa Spraw Wewnętrznych w dniu 20 marca $1922 \mathrm{r}$.

32 Tamże.
} 
dolarów. Jednak już na bardzo wczesnym etapie zdano sobie sprawę, że sytuacja ekonomiczna nie gwarantuje żadnej stabilności cen i szacowany budżet może ulegać szybkim zmianom ${ }^{33}$. Już w maju $1922 \mathrm{r}$. Towarzystwo Popierania Szkoły Pielęgniarek przy Szpitalu Starozakonnych w Warszawie zwróciło się do Jointu z prośbą o zwiększenie budżetu na potrzeby szkoły. Kurator i lekarz naczelny złożyli w biurze AJJDC następujące pismo:

Przy niniejszym mamy zaszczyt przesłać do łaskawej wiadomości budżet projektowanej przez nas wzorcowej szkoły pielęgniarek, ułożony przed 4-a miesiącami. Budżet ten musi być podwyższony co najmniej o 30\% skutkiem znacznej zwyżki cen rynkowych w ostatnich czasach. Załączamy również program wykładów, opracowany przez poszczególnych Ordynatorów, który jednak jeszcze będzie uzupełniony i wtedy dopiero zatwierdzony. Szkołę wraz z internatem mamy zamiar pomieścić w obszernym lokalu domu administracyjnego Szpitala Starozakonnych, specjalnie do tego przysposobionym, jak to już W.W.P.P. wiadomo z planu Im przez nas w dniu $12 \mathrm{Kwietnia}$ r. b. przesłanego.

Otworzyć szkołę chcemy koniecznie na jesieni roku bieżącego, na urządzenie jej potrzebujemy niezwłocznie znacznych sum, dlatego też już teraz zwracamy się do W.W.P.P. z uprzejmą prośbą o łaskawe wyasygnowanie na ten cel funduszów, a to zgodnie z Ich oświadczeniem w liście z dnia 25 Kwietnia r. b.

Jednocześnie komunikujemy, iż do opracowania projektu gmachu specjalnego dla tego celu już przystąpiono, i o ile będziemy rozporządzać odpowiednimi funduszami, budowę tę uskuteczniemy. Odnośne plany nie omieszkamy W.W.P.P. w swoim czasie nadesłać ${ }^{34}$.

Na budżet szkoły składały się wydatki jednorazowe przeznaczone na kompletne umeblowanie i wyposażenie szkoły (warte $7 \mathrm{mln}$ marek polskich) oraz wydatki na utrzymanie szkoły, w tym pensje dla personelu oraz utrzymanie 20 uczennic i 9 osób z personelu (ponad 1 mln marek polskich) ${ }^{35}$. Według majowego pisma do Amerykańskie-

33 JDC Archives NY AR191232/4/25/3/0149. List B. Flexnera do Josephine Goldmark datowany na $10 \mathrm{kwietnia} 1922 \mathrm{r}$.

34 JDC Archives NY AR191232/4/25/3/0336. Projekt budżetu sporządzony przez TPSP na miesiąc maj $1922 \mathrm{r}$.

${ }^{35}$ Marka polska (skrót: mkp) jako waluta obowiązywała od 9 grudnia 1916 r. na okupowanych przez Cesarstwo Niemieckie terenach Królestwa Polskiego, a następnie w Rzeczypospolitej Polskiej. 1 marka polska odpowiadała 100 fenigom. Kurs marki spadł z 9 mkp za 1 dolara amerykańskiego w 1918 r. do 6375000 mkp za dolara pod koniec $1923 \mathrm{r}$. W wyniku reformy pieniężnej z 29 kwietnia $1924 \mathrm{r}$. marka polska została zastąpiona przez polskiego złotego. 
go Komitetu Rozdzielczego program nauczania miał obejmować 18 godzin wykładów i 14 godzin zajęć praktycznych tygodniowo. W pierwszym semestrze wykłady miały odbywać się z następujących przedmiotów: anatomia $\mathrm{z}$ fizjologią, higiena $\mathrm{z}$ bakteriologią i pielęgniarstwo (z podziałem na grupy, na terenie szpitala) oraz trzy godziny zajęć ogólnokształcących obejmujących pogadanki z zakresu nauk przyrodniczych (biologii, estetyki, etyki, historii i kultury oraz psychologii).

W drugim semestrze planowano 10 godzin wykładów i 35 godzin zajęć praktycznych, rozpoczynających się o 8.30 rano, na oddziałach szpitalnych: chorób wewnętrznych, chirurgicznym, chorób oczu, chorób nerwowych i chorób piersiowych. Do obowiązków uczennic miał należeć dozór nad czystością całego oddziału, mycie i czesanie chorych, zmiana bielizny osobistej i pościelowej chorym, usługiwanie im, karmienie pacjentów leżących, pomiary temperatury i tętna. Nadzór nad uczennicami miał sprawować ordynator oddziału. W ramach zajęć teoretycznych kontynuowane miało być nauczanie anatomii z fizjologią, higieny z bakteriologią oraz zajęcia ogólnokształcące. Teoretyczne wykłady z zakresu pielęgniarstwa miała zastąpić nauka podstaw patologii ogólnej ${ }^{36}$.

W trzecim semestrze zajęcia praktyczne miały zajmować 42 godziny tygodniowo. Dodatkowo uczennice miały obowiązek odbyć dwa nocne dyżury tygodniowo. $Z$ zajęć teoretycznych miała pozostać jedynie patologia. Planowano także nauczanie podstaw farmakologii i masażu leczniczego. Zajęcia praktyczne chciano zorganizować grupami w oddziałach: ginekologicznym, położniczym, chorób wewnętrznych, zakaźnym, psychiatrycznym. Uczennice miały uczyć się wykonywania: opatrunków, kompresów, irygacji, lewatywy i iniekcji, a także nadzoru nad pacjentem po operacji. Zajęcia na sali operacyjnej obejmować miały naukę znieczulania chloroformem oraz asystowania przy zabiegach.

Czwarty semestr uczennice miały ćwiczyć w jednym tylko oddziale szpitalnym, doskonaląc swoje umiejętności. Tak zwany patent miały otrzymywać po dwóch latach nauki i zdaniu egzaminu oraz zaliczeniu zajęć praktycznych. Od kandydatek na posady szpitalne oczekiwano, że będą sumienne, taktowne, inteligentne, samodzielne, zaradne, empatyczne oraz że będą „miłowały swój zawód” ${ }^{37}$. Jednak Szkoła Pielę-

36 JDC Archives NY AR191232/4/25/3/0336. Projekt budżetu sporządzony przez TPSP na miesiąc maj $1922 \mathrm{r}$.

${ }^{37}$ Tamże. 
gniarstwa przy Szpitalu Starozakonnych nie gwarantowała przyjęcia do pracy w szpitalu po uzyskaniu ,patentu”38.

Szkoła miała być zupełnie niezależna od szpitala, w którym miały być prowadzone tylko zajęcia praktyczne. Co więcej, Zarząd Szkoły mógł zawierać umowy z innymi szpitalami. Według dr SyrkinBinsztejnowej kierownictwo powinien objąć Zarząd, składający się z przedstawicieli: TPSP, Szpitala Starozakonnych, Zarządu Szkoły Pielęgniarek przy Towarzystwie „Przyjaciół Dzieci”, Zarządu Szkoły Pielęgniarek przy Związku Kobiet Żydowskich oraz dyrektorki Szkoły. Tak utworzony Zarząd zwrócił się do Departamentu Medyczno-Sanitarnego JDC z prośbą o wybór i zaangażowanie dyrektorki ${ }^{39}$.

15 czerwca 1922 r., na prośbę TPSP, Zarząd Miasta zezwolił na umieszczenie Szkoły w budynku tzw. domu administracyjnego Szpitala Żydowskiego, oddając bezpłatnie lokal do dyspozycji TPSP na pięć lat ${ }^{40}$. Pomieszczenia miały zostać odrestaurowane i przebudowane zgodnie z potrzebami (szkoła z internatem dla 25 uczennic) ${ }^{41}$. Początkowo sądzono nawet, że uda się pozyskać w niedługim czasie własny budynek $^{42}$. Niemniej należało przystosować przeznaczone na Szkołę pomieszczenia tak, by móc przyjąć pierwszą turę uczennic. Budynek administracyjny mieścił się niedaleko bramy wejściowej na teren Szpitala Starozakonnych. Do użytku Szkoły oddano część pierwszego oraz drugie piętro tego budynku. Na pierwszym piętrze mieściła się część administracyjna, kancelarie (ogólna, dyrektorki i instruktorek), sale wykładowe, ćwiczebna kuchnia dietetyczna, laboratorium i sale ćwiczeń pielęgniarskich, jak również część pomieszczeń internatu: salon dla uczennic, jadalnia, „wypoczywalnia” i pokoje sypialne dla nocnych dyżurnych. Na drugim piętrze znajdowały się 5-6-łóżkowe

${ }^{38}$ Tamże.

${ }^{39}$ JDC Archives NY AR191232/4/25/3/0352. List Z. Syrkin-Binsztejnowej do dyrektora Departamentu Medyczno-Sanitarnego Jointu w Warszawie dr. Jacoba Goluba, $\mathrm{z}$ dnia 30 czerwca $1922 \mathrm{r}$.

${ }^{40}$ Tamże. Szerzej na temat Szpitala Starozakonnych pisała Z. Podgórska-Klawe, Szkoła Pielęgniarek na Czystem w Warszawie, [w:] B. Urbanek (red.), Zawód pielegniarki na ziemiach polskich w XIX i XX wieku, Warszawa 2008, s. 218. Autorka artykułu powołuje się na prospekt: Szkoła Pielęgniarstwa przy Szpitalu Starozakonnych w Warszawie 1923/1928, Ułożyła S. Schindlerówna, Warszawa 1928.

${ }_{41}$ JDC Archives NY AR191232/4/25/3/0352. List Z. Syrkin-Binsztejnowej do dyrektora Departamentu Medyczno-Sanitarnego Jointu w Warszawie dr. Jacoba Goluba z dnia 30 czerwca 1922 r. Z. Podgórska-Klawe, dz. cyt. Autorka artykułu powołuje się na prospekt: Szkoła Pielegniarstwa..., dz. cyt.

42 JDC Archives NY AR191232/4/25/3/0336. Projekt budżetu sporządzony przez TPSP na miesiąc maj $1922 \mathrm{r}$. 
sypialnie dla starszych uczennic i dwa pokoje większe, po 12-14 łóżek, w których mieszkały uczennice najmłodszego kursu, tzw. probantki ${ }^{43}$.

Magistrat przyznał Szkole na Czystem subsydium, równe otrzymywanemu przez WSP, w wysokości relatywnej do liczby uczennic. Nie były to jednak środki wystarczające na założenie placówki, Towarzystwo zwróciło się więc z prośbą o pomoc do AJJDC, który dzięki poparciu swego europejskiego przedstawiciela dr. Bernarda Kahna przekazał Towarzystwu środki na urządzenie szkoły.

30 czerwca 1922 r. dr Syrkin-Binsztejnowa, członkini Towarzystwa Popierania Szkoły Pielęgniarek, napisała list, w którym przedstawiła dyrektorowi Departamentu Medyczno-Sanitarnego AJDDC w Polsce Jacobowi Golubowi stopień zaawansowania prac nad „sprawą urzeczywistnienia szkoły"44. Kierownictwo powstającej Szkoły objął Zarząd składający się z przedstawicieli TPSP, Towarzystwa Przyjaciół Dzieci (TPD) oraz Związku Kobiet Żydowskich (ZKŻ), jak i dyrektorki Szkoły (jeszcze niepowołanej).

Planowany budżet opiewał na $36 \mathrm{mln}$ marek polskich, jednak dr Syrkin-Binsztejnowa pisała w swoim raporcie, że na skutek dewaluacji marki polskiej koszt prac stale wzrasta i powinno się go szacować z wyprzedzeniem jako dwa razy większy ${ }^{45}$. Środki finansowe potrzebne były na prace remontowe, wyposażenie pokoi i sal wykładowych, kuchni, jadalni oraz na ubrania i pomoce szkolne. Przewidziane wynagrodzenie personelu obejmowało: dyrektorkę Szkoły, cztery instruktorki oraz pracowników socjalnych (sprzątaczki, praczki, służące, kucharzy, pomoce kuchenne). W budżecie przewidziano także wynagrodzenie dla wykładowców, opłaty za światło i ogrzewanie oraz wyżywienie. Budżet został zatwierdzony 30 czerwca 1922 r. ${ }^{46}$ Początkowo wydatki na urządzenie Szkoły szacowano na $19 \mathrm{mln}$ marek polskich, a na jej utrzymanie blisko $17,5 \mathrm{mln}$ marek i 8,5 tys. dolarów. Połowę kosztów pokryć miało TPSP, lecz wobec wzrastających cen, z którymi „ofiarność nie idzie w parze”, było wątpliwe, czy zdoła przeznaczyć na ten cel nawet $25 \%$ całej

${ }^{43}$ I. Kowalkowska, Historia Szkoły Pielegniarstwa przy Szpitalu Starozakonnych na Czystem, Praca licencjacka wykonana pod kierunkiem prof. dr. hab. Marka Wichrowskiego w Zakładzie Historii Medycyny i Filozofii WUM, Warszawa 2009, s. 10.

44 JDC Archives NY AR191232/4/25/3/0352. List Z. Syrkin-Binsztejnowej do dyrektora Departamentu Medyczno-Sanitarnego Jointu w Warszawie dr. Jacoba Goluba z dnia 30 czerwca $1922 \mathrm{r}$.

${ }^{45}$ JDC Archives NY AR191232/4/25/3/0350. Raport dr. Z. Syrkin. Projekt budżetu w języku angielskim.

${ }^{46}$ Tamże. 
sumy ${ }^{47}$. W kolejnych miesiącach plany budżetowe trzeba było aktualizować co miesiąc ${ }^{48}$.

Według planu przedstawionego w czerwcu 1922 r. przez dr SyrkinBinsztejnową przy Szkole Pielęgniarstwa miał powstać internat dla uczennic. Nauka i utrzymanie dziewcząt w internacie miały być bezpłatne. Okres próbny miał trwać trzy miesiące i za ten czas przewidywano opłatę. Jeśli uczennica zostałaby przyjęta, następować miał zwrot wpłaty. Pierwszeństwo w naborze miały uczennice z prowincji, ale i one musiały spełniać następujące warunki:

1. Wiek od 18 do 35 lat,

2. Dobre zdrowie potwierdzone badaniem lekarskim przez wyznaczonego lekarza,

3. Sześcioklasowe wykształcenie,

4. Stan wolny,

5. Zgoda na pobyt w internacie przez cały czas trwania nauki,

6. Zgoda na podjęcie pracy tam, gdzie skieruje ją Zarząd Szkoły.

Ostatecznie ustalono, że podstawowy kurs nauczania będzie trwać dwa lata, w przerwie letniej uczennicom przysługiwać miały cztery tygodnie wakacji. Program nauki miał początkowo obejmować aż 20 przedmiotów medycznych ${ }^{49}$.

W lipcu 1922 r. dr Syrkin-Binsztejnowa pisała do biura Jointu $\mathrm{w}$ Warszawie na temat trudnej sytuacji w związku z propozycją połączenia nowo powstającej szkoły z istniejącymi już placówkami działającymi przy Związku Kobiet Żydowskich (ZKŻ) ${ }^{50}$ i przy Towarzystwie Przyjaciół Dzieci (TPD). ZKŻ prowadziło kursy pielęgniarstwa, a szkoła pielęgniarstwa pediatrycznego działała przy szpitalu Bersohnów-Baumanów w Warszawie. Doktor Syrkin-Binsztejnowa pełniła w tym sporze rolę arbitra, a ze strony Szkoły Pielęgniarstwa przy Szpitalu Starozakonnych występowali dr Aron Sołowiejczyk ${ }^{51}$

47 JDC Archives NY AR191232/4/25/3/0352. List Z. Syrkin-Binsztejnowej do dyrektora Departamentu Medyczno-Sanitarnego Jointu w Warszawie dr. Jacoba Goluba $\mathrm{z}$ dnia 30 czerwca $1922 \mathrm{r}$.

${ }^{48}$ JDC Archives NY AR191232/4/25/3/0377. List Z. Syrkin-Binsztejnowej do dyrektora siedziby AJJDC w Warszawie Jacoba Goluba datowany na 27 września $1922 \mathrm{r}$.

49 JDC Archives NY AR191232/4/25/3/0352. List Z. Syrkin-Binsztejnowej do dyrektora Departamentu Medyczno-Sanitarnego Jointu w Warszawie dr. Jacoba Goluba $\mathrm{z}$ dnia 30 czerwca $1922 \mathrm{r}$.

${ }^{50}$ Związek Kobiet Żydowskich (ZKŻ), jid. Yiddishe Froyen Asosiatsiye (YFA), organizacja powstała w 1918 r. z inicjatywy Rokhl Stein, Lei Proshansky i Puah Rakovsky. W 1920 r. ZKŻ połączył się z syjonistyczną organizacją Women's Organization of the Zionist Movement, stając się jej delegaturą w Polsce.

${ }^{51}$ Orko vel Aron, Andrzej Sołowiejczyk, lekarz chirurg, ur. 1865 r., dpl. 1893, ordynator w Szpitalu na Czystem. 
i inż. Weisblat, ze strony ZKŻ dr Berkenheim i dr Rotstadt ${ }^{52}$, natomiast $\mathrm{w}$ imieniu TPD dr Anna Braude-Hellerowa ${ }^{53}$ i dr Zaks ${ }^{54}$. Ostatecznie, po pięciogodzinnych obradach 21 czerwca postanowiono, że:

1. Internat przy ul. śliskiej, w którym mieszkały uczennice szkoły przy szpitalu bersohnów i baumanów, będzie funkcjonował do czasu otwarcia szkoły na czystem, a uczennice $z$ tej placówki będą przyjmowane na preferencyjnych warunkach do nowej szkoły. jeżeli w szkole przy śliskiej pozostanie mniej niż osiem uczennic, placówka zostanie zamknięta, w przeciwnym razie będzie działała do 1 maja $1923 \mathrm{r}$.

2. Szkoła prowadzona przez zkż będzie działała do 1 stycznia 1923 r., otrzymując dotacje jak dotychczas, i będzie mogła nadal korzystać z oddziałów szpitala starozakonnych dla potrzeb szkolenia swoich uczennic.

Pomimo wypracowanego kompromisu przedstawiciele szkoły przy ZKŻ odmówili podpisania ugody, co spowodowało narastanie konfliktu. Doktor Syrkin-Binsztejnowa spodziewała się, że w zaistniałej sytuacji także współpraca ze szkołą na Śliskiej nie będzie przebiegała bez zakłóceń. Aby nie zaogniać sytuacji, proponowała utrzymanie wsparcia dla nich szacowanego na 300 tys. marek polskich do maja $1923 \mathrm{r}^{55}$

Walne zebranie członków TPSP miało miejsce 19 listopada $1922 \mathrm{r}^{56}$ Wybrano wówczas Zarząd TPSP, w skład którego weszli, zgodnie z art. 11 statutu, kurator Szpitala Starozakonnych inż. Adolf Weisblat, lekarz naczelny dr Jakub Szwajcer, dwóch ordynatorów Szpitala na Czystem i sześciu członków rzeczywistych towarzystwa, pośród których byli lekarze: dr Aron Sołowiejczyk, dr Lubliner ${ }^{57}$, dr Lipsztat ${ }^{58}$, dr Zofia

52 Julian Rotstadt, lekarz neurolog, ur. 1871 r., dpl. 1902, ordynator w Szpitalu na Czystem.

53 Anna Braude-Hellerowa (1888-1943) - lekarka, działaczka społeczno-polityczna i radna Warszawy. W latach 1930-1942 lekarka naczelna Szpitala Dziecięcego Bersohnów i Baumanów w Warszawie. Dama Orderu Virtuti Militari.

${ }_{54}$ W teczkach osobowych lekarzy członków Izby Lekarskiej WarszawskoBiałostockiej znajdują się teczki dwóch lekarzy o tym nazwisku: Łazarza Zaksa, pediatry, ur. 1893 r., dpl. 1922 r. oraz Marka Zaksa, lekarza chorób wewnętrznych, ur. 1897 r., dpl. $1928 \mathrm{r}$.

55 Pierwsza próba wypracowania wspólnego stanowiska miała miejsce w dniu 21 maja 1922 r. JDC Archives NY AR191232/4/25/3/0361. List dr Z. Syrkin-Binsztejnowej do S.M. Schmidt z dnia 10 lipca $1922 \mathrm{r}$.

56 JDC Archives NY AR191232/4/25/3/0392. List dr. Szwajcera do AJJDC, datowany na 13 października $1922 \mathrm{r}$.

57 Prawdopodobnie był nim Stanisław Leopold Lubliner (1863-1937), lekarz chorób płucnych i otolaryngolog. Zbiory GBL.

${ }^{58}$ Prawdopodobnie był nim Jakub Lipsztat (1875-1939), lekarz chorób wewnętrznych i nerwowych. Zbiory GBL. 
Amelia Greenwald i Szkoła Pielęgniarstwa przy Szpitalu Starozakonnych...

Syrkin-Binsztejnowa i dr Goldflam ${ }^{59}$. Brakowało wówczas jeszcze dyrektorki Szkoły oraz przedstawiciela Jointu.

\section{Wybór Amelii Greenwald}

W grudniu 1922 r. podjęto decyzję w sprawie obsady stanowiska dyrektorki powstającej Szkoły Pielęgniarstwa przy Szpitalu Starozakonnych na Czystem. Została nią Amelia Greenwald. Pracujący na miejscu Zarząd oczekiwał jej z niecierpliwością ${ }^{60}$. Oprócz niej brano pod uwagę kandydatury m.in. panny Landy i panny Klombers - obie miały doświadczenie w pracy w Palestynie, panny Deutsch związanej z Henry Street Settlement, panny Hay, która nie była niestety Żydówką, i pozbawionej zdolności praktycznych panny Levine ${ }^{61}$.

W połowie stycznia $1923 \mathrm{r}$. Amelia Greenwald otrzymała od Bernarda Flexnera umowę, w której zgadzała się objąć posadę dyrektorki na okres dwóch lat, licząc od lutego 1923 r., z zastrzeżeniem, że jeśli będzie to potrzebne, pozostanie dłużej. Umowa określała ponadto wynagrodzenie i tryb angażowania asystentki i innych pracowników oraz obligowała ją do sporządzania regularnych raportów (suma przeznaczona na organizację szkoły opiewała na 35 tys. dolarów), jak i sporządzenia curriculum, które byłoby wzorowane na modelu amerykańskim, jednak uwzględniałoby czynniki lokalne ${ }^{62}$. Jakkolwiek zalecano Greenwald aktywną współpracę z miejscowymi organizacjami, jak np. TOZ, to podkreślano, że jedynym komitetem, wobec którego jest odpowiedzialna i zależna, jest Komitet Spraw Medycznych AJJDC w Nowym Yorku (Committee on Medical Affairs) ${ }^{63}$.

Oficjalnie Amelia Greenwald objęła swoje stanowisko 22 lutego 1923 r. Do Warszawy przyjechała w marcu w towarzystwie asystentki, dyplomowanej pielęgniarki Ruth Hoffman, absolwentki studium na-

${ }^{59}$ Prawdopodobnie był nim Samuel Goldflam (1852-1932), lekarz neurolog, prezes i współzałożyciel Towarzystwa Przyjaciół Dzieci.

${ }_{60}$ JDC Archives NY AR191232/4/25/3/0369. List kuratora Szpitala Starozakonnych inż. Weisblata i lekarza naczelnego dr. Szwajcera do AJJDC z dnia 21 września 1922 r.

61 JDC Archives NY AR191232/4/25/3/0149. List B. Flexnera do Josephine Goldmark datowany na 10 kwietnia 1922 r. JDC Archives NY AR191232/4/25/3/0178. List Williama J. Macka do Grace Allison datowany na 6 sierpnia 1922 r. JDC Archives NY AR191232/4/25/3/0179. List G. Allison do W.J. Macka z dnia 15 września 1922 r.

62 Dodano m.in. zajęcia związane z prowadzeniem domu oraz gimnastykę. JDC Archives NY AR/191232/4/25/0870. Maszynopis napisany przez A. Greenwald (bez daty, bez tytułu).

${ }^{63}$ JDC Archives NY AR191232/4/25/3/0218. Umowa datowana na 17 stycznia $1923 \mathrm{r}$. pomiędzy Amelią Greenwald a Bernardem Flexnerem. 
uczycielskiego przy Uniwersytecie Columbia ${ }^{64}$. Pierwsze spotkanie komitetu organizacyjnego miało miejsce 10 kwietnia $1923 \mathrm{r}^{65} \mathrm{~W}$ liście, będącym raportem ze spotkania, pisała, że jakkolwiek członkowie komitetu są bardzo zaangażowani i głęboko przejęci organizacją szkoły, to mają niewielkie pojęcie o tym, co faktycznie oznacza takie przedsięwzięcie.

Pieniądze przeznaczone przez AJJDC na remont przydzielonych pomieszczeń zostały dobrze wykorzystane. Sale na I i II piętrze budynku administracyjnego Szpitala Starozakonnych zostały odnowione i umeblowane. Mimo to Greenwald zdawała sobie sprawę, że szkoła musi dysponować znacznie większą przestrzenią niż zaoferowane przez administrację szpitalną pomieszczenia ${ }^{66}$. Pokoje przeznaczone na osobisty użytek dyrektorki składały się z małej sypialni i tej samej wielkości pokoju dziennego. Dla probantek przygotowano 12 sypialni, każda z dwoma łóżkami, szafą i stołem. Jeden z pokoi, nieco większy od pozostałych, został przeznaczony dla gospodyni. Była tam też składowana pościel. Niewielki pokoik przeznaczono dla służących. Jedno z pomieszczeń przygotowano na biuro. Znajdowały się tam ponadto całkiem duża jadalnia, salon, niewielka kuchnia, w której można było odgrzać posiłek, dwie bardzo małe łazienki z prysznicami - absolutnie niewystarczające na potrzeby tak wielu osób. Nie przewidziano łazienek dla służących, pralni ani większej liczby toalet. Jedna z sal została przeznaczona do nauki przedmiotów teoretycznych i praktycznych, jednak absolutnie nie spełniała podstawowych wymagań. Aby uzmysłowić członkom Zarządu, jak powinny wyglądać pomieszczenia dydaktyczne, Greenwald zorganizowała wspólne zwiedzanie budynku Warszawskiej Szkoły Pielęgniarstwa.

Wizyta w szkole prowadzonej przez Helen Bridge zrobiła na członkach Zarządu ogromne wrażenie, zwłaszcza fakt, że na potrzeby szkoły przeznaczono aż dwa pawilony na terenie szpitala przy ul. Smolnej 6. Wszystkie pomieszczenia dla uczennic były obszerne, widne i wygodnie urządzone oraz dobrze wyposażone $\mathrm{w}$ pomoce naukowe. Także warunki sanitarno-higieniczne były o wiele lepsze niż w budynku na Czystem. Po tej wizycie członkowie Zarządu nabrali przekonania, że muszą zabezpieczyć dodatkowe pomieszczenia na działalność Szkoły, zwłaszcza jeśli planowano przyjmowanie kolejnych roczników. Pan-

${ }^{64}$ JDC Archives NY AR191232/4/25/3/0222. Formularz i dokumenty zgłoszeniowe Ruth Hoffman, datowane na 2 lutego $1923 \mathrm{r}$.

${ }^{65}$ JDC Archives NY AR191232/4/25/3/0237. List A. Greenwald do Komitetu Spraw Medycznych AJJDC (B. Flexnera), datowany na 20 kwietnia $1923 \mathrm{r}$.

66 JDC Archives NY AR191232/4/25/3/0237. List A. Greenwald do Komitetu Spraw Medycznych AJJDC (B. Flexnera), datowany na 20 kwietnia 1923 r. 
na Greenwald planowała przeprowadzić remont strychu, by stworzyć tam pomieszczenia sypialne dla przyszłych uczennic. Koszt takiej rozbudowy inż. Eber wycenił wstępnie na 6-10 tys. dolarów ${ }^{67}$.

\section{Pierwszy nabór}

Wstępny plan i program nauki w Szkole Pielęgniarstwa został przedstawiony Komitetowi Organizacyjnemu 3 maja 1923 r. podczas uroczystego obiadu zorganizowanego przez dr. Goluba w głównej siedzibie Jointu przy al. Szucha 6. Przetłumaczył on dokumenty przygotowane przez dyrektorkę na język polski (w tym curriculum) i wręczył je uczestnikom ${ }^{68}$. Amelia Greenwald przedstawiła własne curriculum sporządzone według zaleceń pierwszej w Stanach Zjednoczonych organizacji pielęgniarskiej United States League of Nursing ${ }^{69}$. W obszernym dokumencie znalazły się następujące zagadnienia: konieczność rozbudowy Szkoły lub budowy zupełnie nowego budynku celem stworzenia dodatkowych miejsc dla uczennic, tak aby można było pomieścić kolejne nabory dziewcząt, zatrudnienie dodatkowego personelu, w tym niezbędnych instruktorek pielęgniarstwa i dietetyczki oraz nauczycieli przedmiotów medycznych, sformułowanie kryteriów naboru probantek, organizacja biura Szkoły wraz z archiwum, wysokość czesnego ${ }^{70}$, opieka nad chorymi uczennicami, egzaminy końcowe oraz dyplom i odznaka Szkoły. Greenwald proponowała także, aby szkolenie rozpoczynał pięciomiesięczny kurs przygotowawczy służący weryfikacji probantek i ich umiejętności ${ }^{71}$. Po zaakceptowaniu przez Zarząd przedstawionych przez nią propozycji można było rozpocząć rekrutację probantek.

W czerwcu 1923 r. Amelia Greenwald dwukrotnie raportowała sytuację związaną $\mathrm{z}$ naborem dziewcząt, pisząc bezpośrednio do biura Bernarda Flexnera w Nowym Yorku ${ }^{72}$. W pierwszym raporcie z dnia

67 Tamże.

68 Tamże. Dopisek z dn. 10 maja 1923 r. świadczy o olbrzymim zaangażowaniu dr. Goluba i jego nieocenionej pomocy organizacyjnej i materialnej dla Szkoły.

${ }^{69} \mathrm{Na}$ potrzeby Szkoły przetłumaczono program nauczania nowojorskiej szkoły dla pielęgniarek (The New York State University Nursing Curriculum).

70 Opłata wstępna wynosiła 700 tys. marek i mogła być zapłacona w dwóch ratach. JDC Archives NY AR191232/4/25/3/0284. Orientacyjny plan i program Szkoły Pielęgniarstwa datowany na 2 maja $1922 \mathrm{r}$.

71 JDC Archives NY AR191232/4/25/3/0244. Orientacyjny plan i program Szkoły Pielęgniarstwa datowany na 2 maja 1922 r. JDC Archives NY AR/191232/4/25/0870, Maszynopis napisany przez A. Greenwald (bez daty, bez tytułu).

72 JDC Archives NY AR191232/4/25/3/0280, Drugi raport A. Greenwald datowany na 1 czerwca 1923 r. JDC Archives NY AR191232/4/25/3/0284. Drugi raport z projektem budżetu datowany na 16 czerwca $1923 \mathrm{r}$. 
1 czerwca Greenwald pisała o 110 podaniach, z których 75 spełniało wymogi wyznaczone przez Ministerstwo. Niektóre z kandydatek były studentkami Uniwersytetu Warszawskiego. Na rozmowę i badanie lekarskie zaproszono 45 dziewcząt w turach po dziesięć osób. W kolejnym raporcie, datowanym na 16 czerwca, Greenwald pisała o łącznej liczbie 108 podań. Spośród zaproszonych 45 przyszłych probantek na rozmowy przyjechały 34 dziewczęta. Kandydatki sprawiały w większości dobre wrażenie, lecz niektóre były niedożywione. Lekarz szkolny dr Lubliner wybrał „20 pierwszorzędnych, 10 drugiego wyboru, a 4 odrzucono”. Rozmowy z dziewczętami prowadziła Amelia Greenwald i intendent Szpitala Starozakonnych Ignacy Fliederbaum. Większość przyszłych uczennic mówiła w języku rosyjskim, niektóre po polsku, kilka znało język francuski lub niemiecki ${ }^{73}$. Dziewczęta pochodziły na ogół z dużych miast i dobrze sytuowanych rodzin. Mimo to panna Greenwald nie była $\mathrm{z}$ nich w pełni zadowolona. Uważała, że nie są nauczone czystości i prawdopodobnie z lenistwa nie dbają o swoje otoczenie. Aby zaradzić tej niedogodności, wprowadziła dodatkowe zajęcia, w trakcie których probantki uczyły się obsługi podstawowych urządzeń domowych i dbania o porządek. Tak surowa ocena dziewcząt przez dyrektorkę była związana prawdopodobnie z uprzedzeniami, jakie wobec europejskich Żydów żywili Żydzi amerykańscy, przekonani o ich zacofaniu i nieświadomi tego, przez co przechodzili ich dalecy krewni w Europie ${ }^{74}$.

\section{Otwarcie szkoły}

Uroczystość otwarcia szkoły miała miejsce 8 lipca $1923 \mathrm{r}^{75}$ Obecny na uroczystości był dr Golub, przedstawiciele Zarządu: inż. Weisblat, dr Szwajcer i dr Syrkin-Binsztejnowa ${ }^{76}$. Wśród gości znaleźli się także przedstawiciele Ministerstwa Zdrowia Publicznego, Zarządu Miasta, lekarze i znani Żydzi (nie tylko z Warszawy), jak Abraham Kahn wydawca żydowskiego czasopisma „Forward” („Forverts”) z Nowego

${ }^{73}$ JDC Archives NY AR191232/4/25/3/0284. Orientacyjny plan i program Szkoły Pielęgniarstwa datowany na 2 maja $1922 \mathrm{r}$.

${ }^{74}$ D.K. Heller, dz. cyt., s. 333.

75 W chwili otwarcia szkoły w sierpniu 1923 r. TPSP liczyło 192 członków, w tym 122 lekarzy. JDC Archives NY AR191232/4/25/3/0272. Tłumaczenie na jęz. angielski wycinka prasowego „Kuriera Polskiego”.

${ }^{76}$ W skład Zarządu Szkoły w chwili jej otwarcia oprócz Amelii Greenwald weszli: inż. Weisblat, lekarze: Szwajcer, Sołowiejczyk, Lubliner, Lipsztat, Syrkin-Binsztejnowa, Goldflam oraz panowie: B. Weingart, B. Goldfeder, panna Berkenheim i pan W. Sznurek. 
Yorku czy państwo Held związani z organizacją pomagającą osobom planującym emigrację do USA, Kanady, Afryki Południowej, Australii i Chin (Hebrew Immigrant Aid Society, HIAS). Gości przywitał inż. Weisblat. Przemawiali także dr Szwajcer i dr Golub, rabin dr Bałaban, pierwszy sekretarz poselstwa amerykańskiego Pierre Boal i dyrektorka szkoły Amelia Greenwald ${ }^{77}$. Przybyło także pierwszych 13 probantek, ubranych w różowe uniformy, które odebrano im jednak po uroczystości. Pozostawiono im fartuchy, kołnierzyki i mankiety. Czepki i bawety otrzymać miały ponownie po zdaniu pierwszych egzaminów za kilka miesięcy ${ }^{78}$. Szkoła zrobiła na przybyłych gościach bardzo dobre wrażenie, a relacje z przebiegu uroczystości zamieszczono w gazetach „Kurier Polski” i „Nasz Przegląd”79. Cytowano m.in. wypowiedź dyrektorki, która „wskazała na zasadę uczennic szkoły: spieszenia z pomocą wszystkim bez różnicy wyznania i narodowości, cierpiącym"80.

Zajęcia rozpoczęły się następnego dnia ${ }^{81}$. Jakkolwiek w chwili otwarcia w Szkole działały już kuchnia i pralnia, to potrzebowała ona dodatkowych pomieszczeń w internacie. Negocjacje w tej kwestii w Zarządzie Miasta podjął inż. Weisblat. 17 lipca 1923 r. Magistrat wydał zgodę na rozbudowę budynku i udzielił koncesji ważnej do $1942 \mathrm{r}^{82}$ Tego samego dnia Greenwald napisała najbardziej entuzjastyczny list skierowany na ręce Flexnera. Pozostając cały czas pod wrażeniem uroczystości otwarcia oraz „gradu komplementów”, jaki spadł na nią oraz Zarząd Szkoły, opisywała z detalami jej przebieg. Duma przepełniała jej serce, co wyraziła, pisząc następujące słowa: „według mojej bezstronnej opinii ta szkoła będzie najlepszym i najdłużej trwającym pomnikiem, jaki Joint może pozostawić po sobie w Europie" ${ }^{83}$.

Łącznie naukę rozpoczęło 21 probantek i - jak pisała dyrektorka w liście do B. Flexnera - „uczennice są szczęśliwe i miło jest patrzeć,

77 JDC Archives NY AR191232/4/25/3/0257. Wycinek prasowy z „Naszego Przeglądu" (bez daty).

78 JDC Archives NY AR191232/4/25/3/0258. List A. Greenwald do B. Flexnera, datowany na 17 lipca $1923 \mathrm{r}$.

79 JDC Archives NY AR191232/4/25/3/0275. Wycinek prasowy z „Naszego Przeglądu” (bez daty), JDC Archives NY AR191232/4/25/3/0273. Wycinek prasowy z „Kuriera Polskiego” (bez daty).

80 JDC Archives NY AR191232/4/25/3/0275. Wycinek prasowy z „Naszego Przeglądu" (bez daty).

81 JDC Archives NY AR/191232/4/25/0870. Maszynopis napisany przez A. Greenwald (bez daty, bez tytułu)

82 JDC Archives NY AR191232/4/25/3/0257. Wycinek prasowy z „Naszego Przeglądu" (bez daty).

${ }^{83}$ JDC Archives NY AR191232/4/25/3/0258. List A. Greenwald do B. Flexnera, datowany na 17 lipca $1923 \mathrm{r}$. 
jak rozwijają się dzień po dniu"84. Oprócz przedmiotów zawodowych zorganizowano im także nauczanie języka polskiego, ponieważ większość dziewcząt na co dzień posługiwała się językiem rosyjskim. Dyrektorka nauczała dziewczęta, korzystając z pomocy tłumacza ${ }^{85}$. Bibliotekarką i kierowniczką sekretariatu została panna Broches, stenotypistką panna Seligson, tłumaczką i nauczycielką języka polskiego panna Schwartzberg, gospodynią domu zaś pani Zuchter, która zamieszkała na terenie szkoły wraz z czternastoletnią córką ${ }^{86}$. Instruktorką pielęgniarstwa została panna Hoffman, Amerykanka, niemówiąca po polsku. Prócz wymienionych osób w szkole pracowali: kucharz, pomoc kuchenna, dwie szwaczki (jedna etatowa, druga zatrudniona czasowo), trzy praczki, jeden sprzątacz i dwunastoletni palacz.

W sierpniu panna Hoffman wyjechała do Stanów Zjednoczonych z powodu spraw rodzinnych. Miało jej nie być kilka tygodni ${ }^{87}$. Amelia Greenwald postanowiła pojechać do Poznania w poszukiwaniu nowej instruktorki. Działała tam od 1921 r. Poznańska Wyższa Szkoła Pielęgniarstwa, powstała z inicjatywy Polskiego Czerwonego Krzyża (PCK), Okręgu Wielkopolskiego PCK przy współudziale Amerykańskiego Czerwonego Krzyża. Greenwald wiedziała, że jedna z amerykańskich instruktorek została tam oddelegowana przez ARC i miała nadzieję ją pozyskać. Z Poznania pojechała do Pragi szukać kandydatki w szkole panny Parson. Bezskutecznie. Martwiła się z powodu braku kadry instruktorskiej i podręcznika, problemem była także postępująca dewaluacji pieniądza ${ }^{88}$. Łączny koszt uruchomienia Szkoły liczony we wrześniu 1923 r. oszacowany został na przeszło 42 tys. dolarów (35 tys. dolarów przewidywane od początku i ponad 7 tys. dolarów dodatkowo ${ }^{89}$.

84 JDC Archives NY AR191232/4/25/3/0265. List A. Greenwald do B. Flexnera z dnia 22 sierpnia $1923 \mathrm{r}$. Amelia Greenwald odesłała niezwłocznie jedną z nich do domu, gdy zorientowała się, że jest ona niesubordynowana i może powodować kłopoty. Kolejna odeszła po trzech miesiącach z powodu choroby. JDC Archives NY AR191232/4/25/3/0267, NY AR191232/4/25/3/0290. Po rozbudowie Szkoły przyjmowano na ogół dwa razy w roku po ok. 20 probantek.

${ }^{85}$ S. Mayer, Amelia Greenwald and Regina Kaplan..., dz. cyt., s. 89.

86 JDC Archives NY AR191232/4/25/3/0284. Orientacyjny plan i program Szkoły Pielęgniarstwa datowany na 2 maja $1922 \mathrm{r}$.

87 JDC Archives NY AR191232/4/25/3/0265. List A. Greenwald do B. Flexnera datowany na 22 sierpnia $1923 \mathrm{r}$.

${ }_{88}$ JDC Archives NY AR191232/4/25/3/0267. List A. Greenwald do Ruth Cohn, datowany na 26 sierpnia $1923 \mathrm{r}$.

${ }^{89}$ JDC Archives NY AR191232/4/25/3/0276. List J. Goluba do B. Kahna, datowany na 28 sierpnia $1923 \mathrm{r}$. 
W raporcie pisanym przez Greenwald w listopadzie 1923 r. do Komitetu Spraw Medycznych JDC można przeczytać, że zajęcia teoretyczne ruszyły w październiku. Wśród wykładowców byli następujący lekarze: dr Tubiasz (anatomia i fizjologia), dr Rosenblum (bakteriologia), dr Lichtenberg (farmakologia), dr Sztabholc (bandażowanie), dr Feilchenfeld (higiena osobista). Zajęcia z zakresu pielęgniarstwa praktycznego prowadziła panna Ruth Hoffman, a po jej odejściu Gusta Davidsohn. Amelia Greenwald uczyła historii pielęgniarstwa i etyki. Podstawowe informacje $\mathrm{z}$ zakresu funkcjonowania administracji przekazał dziewczętom intendent szpitala ${ }^{90}$. Jednak sytuacja w Szkole nie była dobra, o czym Greenwald pisała w liście do inż. Weisblata w listopadzie 1923 r. następująco: „Tak jak Pan sobie życzył, przygotowałam listę problemów, która powinna być przedstawiona na jutrzejszym spotkaniu komitetu. Oczywiście byłoby bezsensowne wymienianie poszczególnym problemów jeden za drugim, zwłaszcza że nie mogę włączyć się do dyskusji, aby przedstawić swój punkt widzenia. Dlatego przedstawiam te problemy w postaci raportu, który może być przedmiotem analizy i zapisem stanu rzeczy równocześnie" ${ }^{91}$. Do głównych bolączek dyrektorki należał brak wyposażenia niezbędnego do szkolenia uczennic w oddziałach szpitalnych, konieczność nadbudowy budynku oraz wprowadzenia zmian do statutu związanych z procedurą rekrutacji probantek, które miały m.in. dotyczyć wykształcenia (ukończone minimum sześć klas gimnazjum) oraz opłat wnoszonych przez przyszłe uczennice. Zdaniem Greenwald powinny one wynosić w polskich markach odpowiednio: ekwiwalent 5 dolarów wpisowego, 20 dolarów za semestr próbny. Wpisowe miałoby zostać zwrócone w chwili ukończenia szkolenia.

Nieobecną pannę Hoffman zastępowała czasowo Gusta Davidsohn, która nie posiadała jeszcze dyplomu, a do Szkoły zgłosiła się, aby uzupełnić rozpoczęte gdzie indziej szkolenie (Greenwald nazwała ją senior student nurse $)^{92}$. Przyczyna wyjazdu instruktorki zdawała się mieć naturę osobistą, nie bez znaczenia było też to, że obie Amerykanki żywiły wobec siebie niechęć. Hoffman obiecywała, że po powrocie zostanie w Warszawie na kolejne sześć miesięcy, jednak Greenwald

\footnotetext{
90 JDC Archives NY AR191232/4/25/3/0306. List J. Goluba do B. Kahna, datowany na 7 listopada $1923 \mathrm{r}$.

91 JDC Archives NY AR191232/4/25/3/0517. List A. Greenwald do inż. Weisblata $\mathrm{z}$ dnia 24 listopada $1923 \mathrm{r}$. [tłum. własne].

92 JDC Archives NY AR191232/4/25/3/0306. List J. Goluba do B. Kahna datowany na 7 listopada 1923 r. JDC Archives NY AR191232/4/25/3/0330. List A. Greenwald do B. Flexnera datowany na 27 grudnia $1923 \mathrm{r}$.
} 
wolała kogoś, kto mógłby zadeklarować przynajmniej dwuletni okres pracy $^{93}$. W tym celu udała się na poszukiwania do Niemiec, Francji, Anglii i Danii ${ }^{94}$. W grudniu, jakby przeczuwając nadchodzące wieści od Hoffman i zdesperowana brakiem konkretnego rozwiązania, napisała list do Clary Dutton Noyes, naczelnej pielęgniarki misji ARC w Polsce. List zatytułowała „first S.O.S.” (pierwsze S.O.S.). Prosiła $\mathrm{w}$ nim o pomoc w znalezieniu instruktorki, niekoniecznie Żydówki, lecz mówiącej w języku polskim, jak to sformułował dr Golub: „Language essential, religion unimportant” (Język konieczny, wyznanie nieważne $)^{95}$. Niestety, Noyes nie odpisała.

Sytuacja stawała się coraz bardziej napięta w związku z faktem ukończenia przez probantki kursu wstępnego. Greenwald zwracała się $\mathrm{w}$ tej kwestii do inż. Weisblata, prosząc go o pomoc w przygotowaniu oddziałów szpitalnych na przyjście uczennic. Po wizytacji oddziałów Szpitala Starozakonnych Amelia Greenwald obawiała się, że probantki zastąpią jedynie personel pomocniczy, nie odbywając przewidzianych w regulaminie nauczania ćwiczeń. Proponowała, by jako pierwszy oddział, na którym dziewczęta będą odbywać zajęcia, wyznaczyć oddział chirurgiczny dr. Sołowiejczyka, na którym przebywali ciężko chorzy wymagający faktycznej pomocy pielęgniarskiej ${ }^{96}$. Aby szkolenie przebiegało zgodnie z programem, każda uczennica miała opiekować się pięcioma pacjentami w ciągu dnia i dziesięcioma w trakcie dyżuru nocnego, po którym przewidywano ośmiogodzinny odpoczynek. Wyposażenie oddziału, w którym miały szkolić się dziewczęta, należało uzupełnić o pościel, naczynia i sprzęt medyczny. W oddziałach należało wyznaczyć miejsca, gdzie odbywałyby się zajęcia, łazienkę ze zlewem i bieżącą wodą do mycia i przechowywania naczyń, pomieszczenie przeznaczone do przechowywania pościeli lub ewentualnie szafy przeznaczone na ten cel, pomieszczenie kuchenne, gdzie następowałby podział żywności dostarczonej z kuchni szpitalnej. Raport Greenwald zawierał pełną listę niezbędnego wyposażenia, w tym m.in. sterylizator. Dyrektorka przypominała w liście, że

\footnotetext{
${ }^{93}$ JDC Archives NY AR191232/4/25/3/0321. List A. Greenwald do B. Flexnera datowany na 23 listopada $1923 \mathrm{r}$.

${ }_{94}$ NY AR191232/4/25/3/0290. List A. Greenwald do B. Flexnera datowany na 4 listopada $1923 \mathrm{r}$.

95 JDC Archives NY AR191232/4/25/3/0324. List A. Greenwald do C. Noyes, datowany na 13 grudnia 1923 r. NY AR191232/4/25/3/0290. List A. Greenwald do B. Flexnera datowany na 4 listopada 1923 r. NY AR191232/4/25/3/0278. List J. Goluba do B. Flexnera datowany na 7 listopada $1923 \mathrm{r}$.

${ }^{96}$ JDC Archives NY AR191232/4/25/3/0527. Raport ze spotkania Zarządu Szkoły w dniu 25 listopada $1923 \mathrm{r}$.
} 
wysokie koszty zakupu wymienionych przedmiotów i urządzeń zostaną zrekompensowane przez rosnącą jakość opieki nad chorymi przebywającymi w szpitalu. Była zdania, że administracji powinno zależeć także na współpracy między lekarzami a uczennicami, ponieważ także i to wpływa pozytywnie na wizerunek placówki. Raport zawierał też odniesienie do budżetu Szkoły przewidzianego na grudzień, a raczej kłopotów z pozyskaniem funduszy, do których regularnego przekazywania zobowiązało się TPSP ${ }^{97}$.

Pod koniec listopada 1923 r. Greenwald otrzymała wiadomość, że panna Hoffman nie ma zamiaru wracać do Polski ${ }^{98}$. Przyjęcie kolejnego rocznika dziewcząt uzależnione było od pozyskania choć jednej instruktorki, dlatego też zintensyfikowano poszukiwania ${ }^{99}$. Także i tym razem zawiodły wszystkie nadzieje pokładane we wpływowych osobach w Stanach Zjednoczonych i Europie. Choć z niechęcią, zdecydowano się wówczas umożliwić powrót pannie Hoffman ${ }^{100}$. Jednak ta zdecydowanie odmówiła ${ }^{101}$.

Z końcem roku Szkoła borykała się już nie tylko z brakiem instruktorek. Do głównych zmartwień dyrektorki dołączyły pierwsze problemy wychowawcze związane z niesubordynacją uczennic, które po zakończonym okresie próbnym postanowiły zbuntować się wobec sztywnego regulaminu, nie zachowując ciszy nocnej. Incydent ten zakończył się polubownie, co dało dziewczętom poczucie, że są ,aż i jedynie” uczennicami Szkoły. Kolejne trudności dotyczyły wzajemnych relacji Greenwald z pozostałymi członkami Zarządu Szkoły. Jakkolwiek dyrektorka uważała, że osoby te są niezwykle oddane idei, to dostrzegała ich trudności w podejmowaniu decyzji, powtarzające się absencje na zebraniach, bezczynność, a nawet bezradność, która nie

${ }^{97}$ JDC Archives NY AR191232/4/25/3/0517. List A. Greenwald do inż. Weisblata datowany na 24 listopada 1923 r., JDC Archives NY AR191232/4/25/3/0499. List A. Greenwald do B. Kahna datowany na 26 grudnia $1923 \mathrm{r}$.

98 JDC Archives NY AR191232/4/25/3/0321. List A. Greenwald do B. Flexnera datowany na 23 listopada 1923 r., JDC Archives NY AR191232/4/25/3/0326. Telegram B. Flexnera do biura Jointu w Wiedniu, datowany na 17 grudnia $1923 \mathrm{r}$.

99 JDC Archives NY AR191232/4/25/3/0322. List B. Flexnera do A. Greenwald datowany na 3 grudnia 1923 r., JDC Archives NY AR191232/4/25/3/0497. List B. Kahna do AJJDC w Nowym Yorku wraz z raportem A. Greenwald, datowany na 3 stycznia $1924 \mathrm{r}$. JDC Archives NY AR191232/4/25/3/0499. List A. Greenwald do B. Kahna datowany na 26 grudnia 1923 r., JDC Archives NY AR191232/4/25/3/0517. Raporty Amelii Greenwald pisane do AJDC.

100 JDC Archives NY AR191232/4/25/3/0322. List B. Flexnera do A. Greenwald datowany na 3 grudnia $1923 \mathrm{r}$.

101 JDC Archives NY AR191232/4/25/3/0326. Telegram B. Flexnera do biura Jointu w Wiedniu datowany na 17 grudnia $1923 \mathrm{r}$. 
wróżyła szybkiego przejęcia przez nie zobowiązań płynących z faktu prowadzenia Szkoły. Nie pomogła nawet listopadowa wizyta dr. Goluba na zebraniu Zarządu. Zresztą dr Golub był zdania, że Greenwald nie potrafiła zarządzać komitetem. Uraziło to zapewne dyrektorke, ponieważ w liście do Kahna napisała następujące słowa na ten temat: „Nie chcę, żeby mnie lubili, jeżeli nie zamierzają mi pomagać”"102. Była faktycznie zmartwiona tą sytuacją. Nie pomagał we wzajemnych relacjach także utrudniony kontakt językowy i odmienności kulturowe. Greenwald skarżyła się Kahnowi, że członkowie Zarządu, ich rodziny, przyjaciele, a nawet władze administracyjne Szpitala „po prostu kochają" przyprowadzać do Szkoły gości, przed którymi chwalą się doskonałą organizacją instytucji i uczennicami ,jedynymi w swoim rodzaju" ${ }^{103}$. Surowa opinia dyrektorki została nieco złagodzona, gdy na jej bezwzględny apel dotyczący konieczności pilnego wyposażenia oddziałów szpitalnych w pomoce i sprzęt niezbędny do nauczania nawet stary już wówczas dr Szwajcer ruszył „w miasto”, i chodząc od sklepu do sklepu, zdobywał niezbędne wyposażenie. Gdy dumny powrócił, by zdać jej relację ze swoich starań, ta odrzekła mu: „Bardzo dobrze, tak właśnie funkcjonuje Joint - jeszcze kilka takich wycieczek i wyposażymy jeden oddział szpitalny"104.

W październiku 1923 r. Warszawską Szkołę Pielęgniarstwa opuścił pierwszy rocznik absolwentek. Amelia Greenwald skontaktowała się z Helen Bridge $\mathrm{w}$ sprawie pozyskania jednej z uczennic jako nowej instruktorki do prowadzonej przez siebie Szkoły. Niestety, Bridge powiedziała jej, że Zarząd WSP nie był przychylny propozycji, by absolwentki WSP podejmowały pracę w Szkole przy żydowskim Szpitalu na Czystem.

Problem kadrowy udało się rozwiązać dopiero wiosną 1924 r. Aby pozyskać wykształcone pielęgniarki do pracy w Szkole, Greenwald odbyła w maju podróż do Londynu i Liverpoolu ${ }^{105}$. W efekcie tych poszukiwań zatrudniono trzy angielskie pielęgniarki dyplomowane, panny: Marjory Geary, Donaldson i Elisabeth Lister, które podjęły pracę w maju tego roku: jedna jako instruktorka pielęgniarstwa w klasie probantek, jedna jako pielęgniarka naczelna i instruktorka pielęgniarstwa wojskowego i jedna jako instruktorka higieny i zdrowia publicznego.

102 JDC Archives NY AR191232/4/25/3/0499. List A. Greenwald do B. Kahna datowany na 26 grudnia $1923 \mathrm{r}$.

103 Tamże.

104 Tamże.

105 JDC Archives NY AR191232/4/25/3/0579. Memorandum J. Hymana wysłane do B. Flexnera, datowane na 12 sierpnia $1924 \mathrm{r}$. 
Czwarta z dziewcząt, która miała jeszcze przed sobą egzaminy w amerykańskiej szkole w Paryżu, miała dojechać do Szkoły w sierpniu i zająć się instruktażem związanym z obowiązkami pielęgniarek na sali operacyjnej. Ich wynagrodzenie było istotnie niższe niż instruktorek amerykańskich (otrzymywały 60 dolarów miesięcznie przez pierwsze osiem miesięcy, potem 75 dolarów miesięcznie). Dodatkowo do pracy w charakterze instruktorki zgłosiła się panna Langleben, która była absolwentką szkoły przy Szpitalu Dziecięcym Bersohnów i Baumanów. Rekomendowana przez dr Annę Braude-Hellerową zyskała przychylność Amelii Greenwald, lecz w dalszej korespondencji i dokumentach nie odnaleziono już jej nazwiska ${ }^{106}$. Mimo że sytuacja kadrowa poprawiła się, aby zabezpieczyć płynne nauczanie, Greenwald potrzebowała kolejnych trzech nauczycielek ${ }^{107}$. Plany zakładały, że z chwilą wykształcenia pierwszych uczennic zastąpią one angielskie pielęgniarki i w pełni samodzielnie będą mogły prowadzić Szkołę ${ }^{108}$.

Drugi z ważnych problemów rozwiązano wiosną 1924 r., gdy do użytku oddano nadbudowane piętro budynku ${ }^{109}$. W czasach szalejącej inflacji trudno było zapanować nad stale wzrastającymi cenami towarów i usług, dlatego rozbudowa przedłużyła się o kilka miesięcy. $\mathrm{Na}$ ten cel Joint przeznaczył dodatkowe 10 tys. dolarów ${ }^{110}$. Łączny koszt

106 JDC Archives NY AR191232/4/25/3/0554. Raport A. Greenwald datowany na 25 kwietnia 1924 r. Prawdopodobnie pielęgniarką tą była Irena vel Ira Langleben, późniejsza przełożona pielęgniarek w Szpitalu Starozakonnych na Czystem. Zginęła w getcie warszawskim. AŻIH Sygn. 301/5883 Relacja Sabiny Zenderman-Święcickiej.

${ }_{107}$ NY AR191232/4/25/3/0290. List A. Greenwald do B. Flexnera datowany na 4 listopada $1923 \mathrm{r}$.

108 JDC Archives NY AR191232/4/25/3/0554. Raport A. Greenwald datowany na 26 kwietnia 1924 r. JDC Archives NY AR191232/4/25/3/0579. Memorandum J. Hymana wysłane do B. Flexnera, datowane na 12 sierpnia 1924 r. NY AR191232/4/25/3/0290. List A. Greenwald do B. Flexnera datowany na 4 listopada 1923 r.

109 Nadbudowane piętro miało być gotowe na przyjęcie nowej grupy probantek w lutym 1924 r. Ostatecznie oddano je do użytku w kwietniu 1924 r., JDC Archives NY AR191232/4/25/3/0579. Memorandum J. Hymana wysłane do B. Flexnera, datowane na 12 sierpnia 1924 r., JDC Archives NY AR191232/4/25/3/0363. Kosztorys prac budowlanych sporządzony 16 września 1922 r. przez inż. Stiefelmana. Projekt i jego kosztorys sporządził inż. H. Stiefelman. Uwzględniał on prace murarskie, stolarskie, zduńskie, ciesielskie i ślusarskie na łączną sumę 3,7 mln marek polskich. Na wykończenie lokalu potrzebne były w przybliżeniu kolejne $3 \mathrm{mln}$. Aby zaoszczędzić część tej kwoty, inż. Stiefelman radził, aby pozyskać od Jointu „przybory wodociągowe, kanalizacyjne i kąpielowe, o ile instytucja ta przybory takie jeszcze posiada”.

110 JDC Archives NY AR191232/4/25/3/0276. List J. Goluba do B. Kahna datowany na 28 sierpnia 1923 r., JDC Archives NY AR191232/4/25/3/0290. List A. Greenwald do B. Flexnera datowany na 4 listopada $1923 \mathrm{r}$. W liście tym Greenwald wspomina o pomocy finansowej władz miasta, polegającej na zwolnieniu z opłat najmu przez 5 lat oraz o wydłużeniu umowy najmu do $1945 \mathrm{r}$. 
nadbudowy wyniósł o 500 dolarów więcej ${ }^{111}$. Dzięki pomocy Jointu pomieszczenia przeznaczone dla 65 dziewcząt i 4 instruktorek zostały wyposażone w łóżka, stoły, krzesła ${ }^{112}$. Urządzono także pokój sypialny dla 4 uczennic, które miały tam odpoczywać po nocnym dyżurze. Ponadto powstały 4 nowe łazienki, 2 pomieszczenia do „kąpieli słonecznych" (jedno dla dziewcząt, drugie dla nauczycielek) oraz szeroki korytarz służący także jako czytelnia. Pomieszczenia zwolnione przez uczennice wykorzystano do stworzenia nowych pracowni. Pierwsza odwzorowywała typową salę szpitalną z czterema łóżkami, modelami pacjentów i wszystkimi niezbędnymi przedmiotami do nauki podstawowych technik pielęgniarskich. Druga sala wyposażona została $\mathrm{w}$ tabele i szkielety do nauki przedmiotów teoretycznych. Trzecia była kuchnią składającą się z 6 stanowisk do gotowania. Czwarte z pomieszczeń przeznaczono do nauki podstaw bakteriologii, chemii i podstaw wiedzy o lekach ${ }^{113}$.

Po powiększeniu budynku Szkoły można było planować kolejny nabór uczennic. Tym razem zgłosiło się 90 dziewcząt, z których wybrano wstępnie 30, jednak z uwagi na brak wystarczających dotacji ze strony TPSP pozostawiono jedynie 19 spośród nich ${ }^{114}$. Sytuacja finansowa Szkoły była trudna. Magistrat przeznaczał w 1924 r. miesięcznie 100 dolarów, podobną sumę deklarowało TPSP, co stanowiło łącznie zaledwie $25 \%$ miesięcznych wydatków ${ }^{115}$. Zgodnie z propozycją dyrektorki nowo przyjęte uczennice wniosły opłatę w wysokości 20 dolarów każda i miały dopłacać do swojego utrzymania niewielkie sumy co kwartał116.

Jakkolwiek w 1923 r. Zarząd TPSP wywiązywał się ze swoich zobowiązań finansowych wobec Szkoły (wpłata za listopad wynosiła w przeliczeniu 109 dolarów, zaś za grudzień 147 dolarów), to już w 1924 r. łączna suma wpłaconych od stycznia do kwietnia środków wyniosła niespełna 200 dolarów, czyli o połowę mniej niż zakładano ${ }^{117}$.

111 JDC Archives NY AR191232/4/25/3/0517. List A. Greenwald do inż. Weisblata $\mathrm{z}$ dnia 24 listopada $1923 \mathrm{r}$.

112 Część wyposażenia pochodziła z likwidowanego biura Jointu w Warszawie. Siedzibę przy ul. Nalewki 2a ostatecznie zlikwidowano 31 grudnia 1923 r. JDC Archives NY AR191232/4/25/3/078. List J. Goluba do B. Kahna datowany na 28 września 1923 r.

113 JDC Archives NY AR191232/4/25/3/0517. List A. Greenwald do inż. Weisblata $\mathrm{z}$ dnia 24 listopada $1923 \mathrm{r}$.

114 Tamże.

115 Magistrat przyznał Szkole na Czystem subsydium, równe otrzymywanemu przez WSP, w wysokości relatywnej do liczby uczennic.

116 JDC Archives NY AR191232/4/25/3/0517. List A. Greenwald do inż. Weisblata $\mathrm{z}$ dnia 24 listopada $1923 \mathrm{r}$.

117 JDC Archives NY AR191232/4/25/3/0579. Memorandum J. Hymana wysłane do B. Flexnera, datowane na 12 sierpnia $1924 \mathrm{r}$. 
W październiku dyrektorka wyjechała na święta do Berlina, gdzie spotkała się z B. Kahnem. Prawdopodobnie przekonała go do swoich racji, bowiem już w listopadzie Kahn pojawił się w Warszawie na spotkaniu z Zarządem w sprawie współpłacenia za Szkołę ${ }^{118}$.

Po okresie poprawy wzajemnych stosunków nastąpił kolejny kryzys w relacjach. Dodatkowo członkowie Zarządu nie stawiali się na comiesięczne zebrania, a zobowiązania finansowe nie były regulowane zgodnie z umową. Dyrektorka skarżyła się na Zarząd, zarzucając jego członkom już nie tylko brak zainteresowania Szkołą, ale także gołosłowność i absolutną nieudolność wobec trudności finansowych, a co najgorsze - także defraudację środków przeznaczonych na potrzeby prowadzonej przez nią placówki na rzecz Szpitala. Greenwald pisała wprost: „Jestem tu jedna przeciwko dziewięciu”"119. Tym razem nawet inż. Weisblat, którego do tej pory zawsze chwaliła, znalazł się po przeciwnej stronie barykady. Ton, w jakim Greenwald sporządziła wrześniowy raport, świadczył o jej ogromnym rozgoryczeniu. Przekazujący go do centrali Jointu w Nowym Yorku dr Kahn napisał, że był on spowodowany irytacją i złością dyrektorki i że zawierał zapewne błędne wnioski. Pisał też, że Amelia Greenwald jest doskonałą kierowniczką Szkoły, jednak więcej od niej żądać nie można, gdyż nie jest dość zręczną dyplomatką, by podołać bardzo skomplikowanej sytuacji panującej w Polsce. Kahn uważał, że jej opinia była przesadzona. Pisał do Flexnera, że:

Panna Greenwald zdecydowanie źle ocenia komitet. Wydaje się także, że nie jest zaznajomiona ze sprawami biznesowymi, co tłumaczy jej błędną interpretację tego typu relacji z Zarządem. Zarząd Szkoły składa się z bardzo oddanych, wpływowych i uczciwych osób. Oczywiście, że są to polscy Żydzi, którzy muszą być mierzeni inną miarą niż obowiązująca dla Żydów amerykańskich, angielskich czy niemieckich ${ }^{120}$.

Ostatecznie, aby poprawić sytuację finansową Szkoły i rozpocząć nauczanie kolejnego rocznika probantek, Joint przyznał, dzięki poparciu samego prezesa Felixa M. Warburga, 15 tys. dolarów jako tzw. wkład końcowy (final contribution) w działalność placówki ${ }^{121}$. Wkrótce

118 JDC Archives NY AR191232/4/25/3/0635. Raport A. Greenwald dla AJJDC, datowany na 5 marca $1925 \mathrm{r}$.

119 JDC Archives NY AR191232/4/25/3/0591. Raport A. Greenwald datowany na 1 września $1924 \mathrm{r}$.

${ }^{120}$ JDC Archives NY AR191232/4/25/3/0600. List B. Kahna do B. Flexnera z dnia 25 września $1924 \mathrm{r}$.

121 JDC Archives NY AR191232/4/25/3/0618. List B. Flexnera do B. Kahna datowany na 28 listopada $1924 \mathrm{r}$. 
znowu dobry nastrój zawitał w mury Szkoły. W listopadzie 1924 r. na terenie Szpitala otworzono wyremontowany pawilon chorób ginekologiczno-położniczych i chorób ocznych (łącznie 130 łóżek) ${ }^{122}$. W żydowskiej gazecie „Nasz Przegląd” można było przeczytać następującą relację:

Wobec licznie zgromadzonych przedstawicieli świata lekarskiego, rady miejskiej i magistratu z prezydentem miasta inż. Jabłońskim oraz wiceprezydentami dr. Rottermundem i Jankowskim na czele, wczoraj w południe odbyło się uroczyste otwarcie nowego, przebudowanego III pawilonu dla chorych ginekologicznych, położniczych i ocznych, ogółem na 130 łóżek w szpitalu żydowskim na Czystem. Przed zwiedzaniem nowego, przebudowanego według najnowszych wymagań techniki pawilonu przemawiali inżynier Weisblat, lawnik magistratu i kurator szpitala żydowskiego dr Jakimiak, ławnik i ordynator szpitala Przemienienia Pańskiego, który skreśliwszy historję rozbudowy szpitala przez powiększenie III i VII pawilonów, podkreślił zasługi lekarza naczelnego dr. J. Szwajcera, Ignacego Fliederbauma, intendenta tego szpitala i innych. Następnie przemawiali prezydent miasta inż. Władysław Jabłoński, który w gorących słowach dziękował wszystkim kierownikom budowy, zachęcając ich do dalszej pracy. Po zwiedzeniu III i VII (wewnętrznego) pawilonów, zaproszono gości do miłych apartamentów szkoły pielęgniarek otwartej w 1923 r., której dyrektorką jest obywatelka amerykańska miss Amelia Greenwald, zaś zastępczynią jej Marjory Geary. Tam odbyło się skromne przyjęcie, podczas którego wygłoszono szereg toastów, podkreślając zasługi inżyniera Weisblatta, p. Fliederbauma, dr. Szwajcera, dyrektorki Greenwald i innych. Szpital żydowski zalicza się obecnie do największych w Warszawie, gdyż może pomieścić 1100 chorych, czyli jest większy o 200 miejsc od szpitala Dzieciątka Jezus ${ }^{123}$.

Podobnej treści informacja znalazła się w czasopiśmie „Hajnt”, z tym że tu autor wspomniał, iż goście wznosili na koniec toast „Niech żyje Ameryka, Polska i Warszawa, i pokój pomiędzy narodami”"124.

\section{Promocja pierwszego zespołu uczennic}

Pierwsza promocja uczennic miała miejsce 11 października $1925 \mathrm{r}$. 14 dziewcząt ukończyło szkolenie, uzyskując dyplom Szkoły Pielę-

122 JDC Archives NY AR191232/4/25/3/0622. Tłumaczenie na język angielski wycinka prasowego z nr 2790 „Naszego Przeglądu”.

123 Tamże.

${ }^{124}$ JDC Archives NY AR191232/4/25/3/0624. Tłumaczenie artykułu z pisma „Hajnt” na język angielski (15 marca 1925 r.). 
gniarstwa ${ }^{125}$. Oficjalna część uroczystości miała miejsce w pawilonie IX Szpitala Starozakonnych ${ }^{126}$. W jej trakcie przemówienia wygłosili: inż. Weisblat, prezydent Warszawy inż. Władysław Jabłoński, Minister Pełnomocny Stanów Zjednoczonych w Polsce John B. Stetson, żona Ministra Pełnomocnego Wielkiej Brytanii Williama Max-Mullera, dr Szwajcer i A. Greenwald ${ }^{127}$.

Dyplomy wręczył absolwentkom inż. Weisblat, dyrektorka zaś odznaki z napisem: „Szkoła Pielęgniarstwa w Warszawie przy Szpitalu Starozakonnych” oraz emblematami zawodu: książką (symbolem wiedzy), lampką Florencji Nightingale (symbolem miłości bliźniego) i wieńcem laurowym (symbolem zwycięstwa). Odebrały je: L. Bielicka, I. Bomszteinówna, F. Blumenkrancówna, P. Dawówna, A. Gołębianka, T. Koppelówna, N. Lubowska, L. Mirocznikówna, M. Prużańska, R.Ch. Reznikówna, S. Schindlerówna, G. Szapirówna, B. Telentówna i R. Goldszmitówna ${ }^{128}$. Spośród nich Szkoła zatrudniła trzy dziewczęta, dziewięciu natomiast Zarząd Miasta zaoferował stanowiska kierownicze i bardzo dobre wynagrodzenie. Jesienią opuściły Szkołę angielskie pielęgniarki, pozostała jedynie panna Geary z jedną polską pielęgniarką do pomocy ${ }^{129}$.

W listopadzie 1925 r. dr Bernard Kahn, dyrektor departamentu medyczno-sanitarnego AJJDC, pisał następujące słowa w liście do biura w Nowym Yorku:

Sytuacja ekonomiczna w Europie Wschodniej jest dziś o wiele gorsza niż w czasie wojny i zaraz po jej zakończeniu, zwłaszcza w Polsce i Besarabii. (...) Nie możemy czekać dłużej, jeśli nie chcemy katastrofy społeczności żydowskiej. (...) Sądziliśmy, że opieka nad dzieckiem, opieka medyczna, tworzenie szkół i inna pomoc może zostać zlikwidowana w ten sposób, że lokalne komitety, mogłyby $\mathrm{z}$ istotną pomocą z naszej strony, przejąć to. Ale dziś nie możemy oczekiwać niczego od Żydów w tych krajach. Są oni biedniejsi niż kiedykolwiek i prawie nie ma pośród nich takich, którym się dobrze powodzi. Nawet dzieci, które

125 JDC Archives NY AR191232/4/25/3/0635. Raport A. Greenwald dla AJJDC datowany na 5 marca $1925 \mathrm{r}$.

126 JDC Archives NY AR191232/4/25/3/0665. Program uroczystości wręczenia dyplomów 11 października 1925 r. wraz z zaproszeniem dla B. Flexnera.

127 Treść przemówień została zamieszczona $\mathrm{w}$ wydawnictwie okolicznościowym „Pielęgniarka. Pismo wydane z inicjatywy słuchaczek szkoły z okazji ukończenia kursu nauk 1-go zespołu Szkoły Pielęgniarek przy szpitalu Starozakonnych w Warszawie w 1925 roku", Warszawa 1926, Biblioteka Narodowa, Sygn. 650.251.

${ }^{128}$ I. Kowalkowska, dz. cyt., s. 19.

129 JDC Archives NY AR191232/4/25/3/0635. Raport A. Greenwald dla AJJDC, datowany na 5 marca $1925 \mathrm{r}$. 
uczyniliśmy samodzielnymi są bez pracy, a instytucje, które powołaliśmy i które były pod nadzorem miejscowych organizacji, nie moga otrzymać pomocy od władz miejscowych ${ }^{130}$.

W kolejnym liście Kahn pisał o pladze samobójstw, odnotowywanych także wśród ludzi należących do rodzin, które były dotąd znane ze swojej dobroczynności wobec żydowskiej biedoty.

\section{Stypendia}

Niemal od samego początku działalności Szkoły Amelia Greenwald była zdania, że część uczennic, prawdopodobnie tych najbardziej zdolnych, powinna wyjechać do Stanów Zjednoczonych, aby kontynuować naukę $\mathrm{w}$ ramach stypendium. $\mathrm{W}$ raporcie $\mathrm{z}$ działalności Szkoły pisanym w połowie 1924 r. wyraziła się jasno w tej kwestii, zauważając, że Fundacja Rockefellera ufundowała takie stypendia dla trzech pielęgniarek, które ukończyły Warszawską Szkołę Pielęgniarstwa. Dziewczęta po powrocie do Warszawy podjęły pracę w swojej szkole. Kolejne siedem dziewcząt oczekiwało na wyjazd. Greenwald napisała: „Jak dotąd nie zaoferowano nam niczego dla naszej szkoły, nie widzę powodu, dla którego nie mieliby zaproponować nam kilku stypendiów. Jeśli Fundacja Rockefellera dałaby nam kilka stypendiów i może jakaś inna fundacja około 5 tys. dolarów na kształcenie w zakresie zdrowia publicznego, to w ciągu kilku lat od teraz to prorokuję, że polscy Żydzi będą w stanie wykonać swoją własną pracę rekonstrukcyjną"131.

Początkowo Greenwald zabiegała o przyznanie stypendiów dla dwóch uczennic $\mathrm{w}$ berlińskiej szkole kształcącej specjalistki w zakresie pielęgniarstwa położniczego i chorób wewnętrznych oraz dla dwóch w podobnej placówce w Anglii. Interesowała się też warunkami przyjęcia uczennic do Bedford College w Londynie, gdzie mogłyby uczestniczyć w szkoleniu podyplomowym organizowanym przez League of Red Cross Societies for International Nurses. Taki kurs trwał rok i kosztował 100 dolarów. Uważała, że dwie uczennice powinny szkolić się w administracji, a jedna w zakresie zdrowia publicznego. W ten sposób przygotowane pielęgniarki mogłyby przejąć zarządzanie Szkołą. Osobą typowaną na zastępczynię Greenwald była najlepsza z uczennic - dwudziestoośmioletnia Perla Daw, która miała za sobą dwuletnie studia na Uniwersytecie, mówiła po polsku, rosyjsku, niemiecku i znała podstawy języka angielskiego. Spośród uczennic,

${ }^{130}$ Z. Szajkowski, dz. cyt., s. 37.

131 JDC Archives NY AR191232/4/25/3/0579. Memorandum J. Hymana wysłane do B. Flexnera, datowane na 12 sierpnia $1924 \mathrm{r}$. 
które uzyskały dyplom jesienią 1925 r., wybrano także Lizę Mirocznik, która aby zostać instruktorką, miała specjalizować się w nauczaniu pielęgniarstwa, oraz Ninę Lubowską, dla której przewidziano szkolenie w zakresie zdrowia publicznego ${ }^{132}$. Ostatecznie udało się pozyskać fundusze na ośmiomiesięczne szkolenie podyplomowe w Szkole Pielęgniarstwa w St. Thomas Hospital w Londynie, którego koszt wynosił 10 dolarów za osobę tygodniowo. Perla Daw po powrocie z Anglii miała wyjechać do Stanów Zjednoczonych na kurs dla instruktorek prowadzony przez jedną z trzech wytypowanych szkół przy uniwersytetach McGill, Yale albo Columbia.

Zmiana dyrektorki Szkoły miała nastąpić w połowie 1926 r. ${ }^{133}$ Ona sama miała od tego momentu jedynie nadzorować pracę Szkoły z Centrali w Berlinie i wziąc udział w egzaminach dyplomowych drugiego kursu, które odbyć się miały jesienią ${ }^{134}$. Zobowiązania finansowe AJJDC wobec Szkoły zakończyły się 30 czerwca 1926 r. ${ }^{135} \mathrm{Z}$ dniem 1 lipca Zarząd TPSP przejął Szkołę, jednak Greenwald pozostała w Warszawie do końca roku, aby służyć swoją radą i pomocą. Komitet Wykonawczy (z siedzibą przy pl. Napoleona 3) w składzie: inż. Weisblat (kierownik), dr Szwajcer (zastępca), Fliederbaum (sekretarz), Bronisław Goldfeder (skarbnik), Stanisław Goldstein (prawnik), dr Stanisław Leopold Lubliner, dr Aron Sołowiejczyk, dr Zofia SyrkinBinsztejnowa, Bernard Weingart wystosował do biura Jointu pismo z wyrazami uznania za trud włożony w poprawę sytuacji zdrowotnej w Polsce i prace rekonstrukcyjne.

W liście pisanym w lipcu 1926 r. do B. Flexnera, Amelia Greenwald wyrażała swój żal związany z faktem, że nie udało jej się pozyskać funduszy i w pełni zrealizować programu stypendialnego. Nie doszedł też do skutku planowany przez nią kurs z zakresu zdrowia publicznego ${ }^{136}$. Batalia o stypendia trwała nadal. W marcu 1927 r. udało się uzyskać zgodę B. Kahna na ufundowanie stypendium dla Sabiny Schindler, która od lipca pełniła obowiązki dyrektorki Szkoły ${ }^{137}$. Jeszcze w mar-

132 JDC Archives NY AR191232/4/25/3/0635. Raport A. Greenwald dla AJJDC datowany na 5 marca $1925 \mathrm{r}$.

133 Tamże.

134 JDC Archives NY AR191232/4/25/3/0627. List B. Kahna do B. Flexnera datowany na 19 marca $1925 \mathrm{r}$.

135 JDC Archives NY AR191232/4/25/3/0642. Listy B. Flexnera do B. Kahna i A. Greenwald, oba datowane na 8 maja $1925 \mathrm{r}$.

136 JDC Archives NY AR191232/4/25/3/0682. List A. Greenwald do B. Flexnera datowany na 26 lipca $1926 \mathrm{r}$.

137 JDC Archives NY AR191232/4/25/3/0688. Telegram A. Greenwald do B. Flexnera $\mathrm{z}$ dnia 1 grudnia $1926 \mathrm{r}$. 
cu 1927 r., będąc już w Nowym Yorku, Greenwald korespondowała w tej sprawie, ustalając wszystkie niezbędne szczegóły jej pobytu na szkoleniu. W liście do B. Flexnera Sabina Schindler dziękowała mu za przychylność w imieniu swoim, personelu i uczennic Szkoły. Jednak i wówczas wyjazd nie doszedł do skutku. Schindlerówna wyjechała do Stanów Zjednoczonych dopiero w jesienią $1928 \mathrm{r}^{138}$ Towarzyszyła jej Estera Szabad, która uzyskała dyplom w 1928 r. Miało to związek z planowanym na styczeń 1929 r. ponownym otwarciem Szpitala Behrsonów i Baumanów. Estera Szabad, po wstępnym kursie języka angielskiego, miała szkolić się na Uniwersytecie Columbia w zakresie pielęgniarstwa pediatrycznego ${ }^{139}$.

\section{Dalsze losy szkoły}

Amelia Greenwald pozostawiła w Warszawie sprawnie działającą placówkę, doskonale wyposażoną i zyskującą coraz lepszą renomę. Jej obowiązki przejęła Sabina Schindlerówna, jedna z uczennic pierwszego zespołu $^{140}$. Początkowo rozważano, czy tak młoda kandydatka powinna obejmować funkcję kierowniczą i proponowano, aby miejsce Greenwald zajęła lekarka. Zwyciężył jednak pierwotny plan dyrektorki ${ }^{141}$. Do czasu jej wyjazdu z Warszawy dyplom otrzymało 48 pielęgniarek, a w Szkole pozostawało kolejne 80 uczennic $^{142}$. Szkoła Pielęgniarstwa przy Szpitalu Starozakonnych w Warszawie otrzymała m.in. odznaczenie przyznane jej przez Wydział Zdrowia Publicznego Ligii Narodów (Division of Public Health of the League of Nations), złoty medal na Międzynarodowej Wystawie Sanitarno-Higienicznej w 1927 r., sama zaś założycielka została odznaczona przez prezydenta Ignacego Mościckiego, jako pierwsza kobieta w historii, Złotym Krzyżem Zasługi ${ }^{143}$. Ale czy wszystkie plany działaczy Jointu urzeczywistniły się z biegiem lat?

138 JDC Archives NY AR191232/4/25/3/0760. Telegram z biura AJJDC do United State Custom House w NY w sprawie przyjazdu Sabiny Schindler i Estery Szabad do Nowego Yorku.

139 JDC Archives NY AR191232/4/25/3/0772. Zapis rozmowy telefonicznej z dnia 8 października $1928 \mathrm{r}$. pomiędzy A. Greenwald a biurem Jointu.

${ }^{140}$ Z. Podgórska-Klawe, dz. cyt., s. 218. Autorka artykułu powołuje się na prospekt: Szkoła Pielegniarstwa..., dz. cyt., s. 220.

${ }^{141}$ L. Blum-Bielicka, Szkoła Pielęgniarstwa przy Szpitalu Starozakonnych $w$ Warszawie (1923-1943), „Biuletyn Żydowskiego Instytutu Historycznego” 1961, z. 4, nr 40, s. 67.

${ }^{142} \mathrm{~W}$ ciągu czterech pierwszych lat przyjęto 81 probantek, z czego dyplom uzyskało zaledwie 49. Z. Podgórska-Klawe, dz. cyt., s. 218. Autorka artykułu powołuje się na prospekt: Szkoła Pielegniarstwa..., dz. cyt., s. 223.

${ }^{143}$ L.E. Turitz, Amelia Greenwald: The Jewish Florence Nightingale, „American Jewish Archives” 1985, nr 37, s. 291-292. 
W 1929 r. na łamach czasopisma „Pielęgniarka Polska” ukazało się podsumowanie dotyczące zatrudnienia absolwentek szkół pielęgniarskich. Według zamieszczonej w nim tabeli spośród dziewcząt, które ukończyły Szkołę przy Szpitalu Starozakonnych: 4 pozostały w Szkole, 43 pracowały w Szpitalu na Czystem, 7 jako pielęgniarki zdrowia społecznego $\mathrm{w}$ Warszawie, po jednej absolwentce zatrudniono w szpitalach w Miedzeszynie, Białymstoku i Łomży ${ }^{144}$. Osiem lat później, według raportu z działalności Szkoły sporządzonego w 1937 r., w trakcie 14 lat jej działalności dyplomy uzyskało 245 uczennic, z czego w Szkole zostało $5 \mathrm{z} \mathrm{nich}^{145}$, 79 pracowało w Szpitalu Starozakonnych na Czystem, 12 w sierocińcach, 2 w Szkole Higieny, $16 \mathrm{w}$ szpitalach i ośrodkach zdrowia, $2 \mathrm{w}$ szpitalu psychiatrycznym, 49 było prywatnymi pielęgniarkami, 39 zaś emigrowało. Nie pracowało $18 \mathrm{z}$ nich, a $2 \mathrm{zmarły}^{146}$. $\mathrm{Z}$ tych cząstkowych danych jasno wynika, że większość dziewcząt pozostała w stolicy, a nie ruszyła, jak początkowo zakładano, do pracy na prowincji. Być może dlatego, że nie rekrutowały się one na ogół z małych miejscowości. Mimo że w prasie żydowskiej zaczęły pojawiać się nawet ogłoszenia o konkursach stypendialnych - przykładowo Lwowskie Towarzystwo Walki z Gruźlicą oferowało w 1930 r. dwa takie stypendia w szkole w Warszawie - liczba studiujących dziewcząt z prowincji nie wzrosła. Warunkiem otrzymania takiego stypendium było zobowiązanie się kandydatki do pięcioletniej służby w miejscu wyznaczonym przez darczyńców. Obiecywano także pobory IX kategorii płacy urzędników państwowych, z których pielęgniarka była zobowiązana zwracać część sumy przeznaczonej na jej szkolenie, jednak nie więcej niż $10 \%$ pensji. $\mathrm{W}$ razie niedotrzymania warunków stypendium należało zwrócić je w gotówce ${ }^{147}$.

W 1937 r. na łamach czasopisma „Chwila” ukazał się krótki artykuł na temat kształcenia żydowskich pielęgniarek, zamieszczony przez Centralę TOZ-u w Warszawie. Autor krytykował dotychczasowe przedsięwzięcia w zakresie szkolenia następującymi słowami:

${ }^{144}$ H. Chrzanowska, O organizacji pielęgniarstwa w Polsce, „Pielęgniarka Polska” 1929, R. 1, nr 1, s. 18.

${ }^{145} \mathrm{Z}$ czasem niektóre uczennice pozostawały w Szkole jako instruktorki, szkoląc swoje młodsze koleżanki. Były wśród nich m.in.: Lola Neuhauz, Dora Leneman, Sara Lejwand, Raja Jacobson-Osserowa, Rachela Rozenblatt i pielęgniarka operacyjna Bajdycz. A. Margolis-Edelman, Ala z „Elementarza”, Warszawa 2011, s. 49.

${ }^{146}$ R. Zalashik, N. Davidovitch, dz. cyt., s. 103.

147 Konkurs na stypendia na dyplomowane pielęgniarki, „Chwila” 1930, nr 3917, s. 11. 
W dziedzinie kształcenia i kwalifikowania żydowskich pielęgniarek zdziałano dotychczas niewiele. Mamy zaledwie dwie żydowskie szkoły pielęgniarskie w państwie - w Warszawie i w Wilnie. Ale i polskich państwowych szkół jest niewiele. $Z$ rocznych sprawozdań wszystkich szkół pielęgniarskich (wyłączając i polskie państwowe) wynika, że liczba absolwentek każdej szkoły, nie przekracza liczby 20 rocznie. Na skutek tego ogólna liczba pielęgniarek kwalifikowanych jest nieznaczna, bo zaledwie 1500 (na całe państwo). (...) Z dotychczasowej praktyki wiemy, że większość uczennic, pochodzących z prowincji liczy na możność częściowego utrzymywania się z lekcyj, ale przy obecnym stanie rzeczy (w zamkniętym internacie) będzie to niemożliwym. Szkoła nie jest jednak w stanie uwzględnić podań licznych kandydatek o ulgi - byłoby więc wskazanym, by miejscowe organizacje (oddziały TOZ-u i inne) umożliwiały niezamożnym kandydatkom uczęszczanie do szkół pielęgniarskich przez stypendia ${ }^{148}$.

Co ciekawe, w 1937 r. Szkoła Pielęgniarstwa na Czystem wznowiła dwukrotne w ciągu roku zapisy. Oprócz dotychczasowych wymagań formalnych kandydatki musiały wykazać „nieskazitelną przeszłość" 149 .

W okresie swojego pobytu w Polsce Amelia Greenwald sporządzała na potrzeby AJJDC regularne raporty. $\mathrm{W}$ chwilach trosk i zwątpień raporty te pełne były wątpliwości, gdy problemy udawało się rozwiązać, biła z nich radość i duma. Dyrektorka chwaliła Szkołę, opisując, jak ogromne wrażenie wywierała na odwiedzających ją osobach. Podkreślała też przychylne opinie zamieszczane w prasie lokalnej i zagranicznej nie tylko przez dziennikarzy, ale także wdzięcznych pacjentów ${ }^{150}$. Dla niej samej stworzenie tej placówki był „największą ambicją jej życia"151. I chociaż narzekała wielokrotnie na współpracujących z nią członków Zarządu Szkoły, to gdy spisywała historię powstawania placówki, zamieściła w niej następujące słowa:

Chcieli mieć nowoczesne pielęgniarki i amerykański system pielęgniarstwa, ale nie mieli pojęcia co oznacza wyszkolenie nowoczesnej pielęgniarki. Nalegali, aby dwudziestoosobowa grupa dziewcząt zajęła się tysiąc dwustoma pacjentami szpitala. Naprawdę wierzyli, że jeden rocznik czyni szkołę, a biały czepek i fartuch czynią z uczennicy pielęgniarkę. Nalegali, by pielęgniarki pracowały pod nadzorem le-

${ }^{148}$ Kształcenie żyd. Pielęgniarek, „Chwila” 1937, nr 6628, s. 9.

149 Wobec większego zapotrzebowania pielęgniarek, „Chwila” 1937, nr 6557, s. 10.

150 JDC Archives NY AR191232/4/25/3/0579. Memorandum J. Hymana wysłane do B. Flexnera datowane na 12 sierpnia $1924 \mathrm{r}$.

151 JDC Archives NY AR/191232/4/25/0870. Maszynopis napisany przez A. Greenwald (bez daty, bez tytułu). 
karzy, i że one, pielęgniarki powinny być moralnie odpowiedzialne za tych tysiąc dwieście pacjentów, i jeszcze finansowo odpowiedzialne za sprzęt szpitalny. I jeszcze, że podpiszą zobowiązanie do pracy na rzecz Szpitala przez pięć lat od uzyskania dyplomu. Niecierpliwość lekarzy, żeby zacząć jak najszybciej szkolenie była problemem samym w sobie, chociaż miała też wydźwięk komiczny. Argumentowali, że czekali na tę szkołę tysiąc lat i teraz, gdy już tam dotarłam nie widzieli powodu, by czekać dłużej. Pytali, dlaczego nie można założyć im czepków i fartuchów i wysłać do pracy na oddziałach szpitalnych? Odpowiadałam, że jeżeli wytrzymali tysiąc lat czekając na szkołę, to mogą poczekać jeszcze sześć miesięcy zanim uczennice zaczną praktyki szpitalne. Osiągnęliśmy kompromis i dziewczęta zaczęły po trzech miesiącach przygotowań. Jakkolwiek lekarze często mieli nieuzasadnione żądania wobec tego co oferowała szkoła, wszyscy byli lojalni, oddani i bardzo dumni z pielęgniarek. (...) Od początku wiedziałam, że szkoła musi być instytucją niezależną, a jej podstawowym celem ma być edukacja uczennic, zaś szpital ma służyć jako jej miejsce - laboratorium treningu praktycznego, tak jak ma to miejsce w przypadku szkolenia studentów medycyny. I niezmiennie stałam na stanowisku, że zawsze trzeba pozostawić lekarza z głębokim przeświadczeniem, że każdy pomysł narodził się w jego umyśle. To podsycało ich zainteresowanie szkoleniem pielęgniarek i budziło dumę z osiągnięć $c^{152}$.

\section{Losy Amelii Greenwald po powrocie do Stanów Zjednoczonych}

O powrocie Amelii Greenwald do Stanów Zjednoczonych donoszono na łamach „Jewish Daily Bulletin” ${ }^{153}$. W wywiadzie udzielonym dziennikarzowi tej gazety Greenwald powiedziała, że nie ma takiej siły w Polsce, która by uczyniła więcej dla dobra ogółu, jak grupa dziewcząt, które idąc do domów, szerzą wiedzę i przyczyniają się do podwyższenia standardów życia zwykłych ludzi. Greenwald była też zdania, że lepiej jest przeznaczyć tysiąc dolarów na wykształcenie jednej pielęgniarki, niż dożywiać biedną rodzinę, która po kilku miesiącach i tak zostałaby bez środków do życia. Nie dlatego, że Greenwald nie widziała ludzkiego cierpienia i biedy, ale dlatego, że prawdziwie wierzyła w misję pracy pielęgniarek, zwłaszcza tych pracujących w tzw.

152 Tamże. Dla podkreślenia odrębności od szpitala, dzięki staraniom Amelii Greenwald, zmieniono nazwę Szkoły na: Szkoła Pielęgniarstwa przy ul. Dworskiej $17 \mathrm{w}$ Warszawie. Szerzej na ten temat: I. Kowalkowska, dz. cyt., s. 13-14.

${ }^{153}$ Amelia Greenwald back in U. S.; Founder of Warsaw Nurses Training School, „Jewish Daily Bulletin” 1927, t. 7, nr 681, s. 3. 
terenie na rzecz poprawy stanu higieny i świadomości żydowskiej biedoty. Wkrótce podjęła ponownie pracę na rzecz Rady Kobiet Żydowskich w Departamencie Rolnictwa i Pracy Wsi (Department of Farm and Rural Work) ${ }^{154}$. W 1932 r. została dyrektorką Szkoły Pielęgniarstwa przy Szpitalu Rothschilda w Palestynie (ang. Nurse's Training School at Rothschild Hospital, Hadassah) ${ }^{155}$. Rok później odeszła na emeryturę. W 1936 r. otworzyła sklep z odzieżą La Vogue w miejscowości Eunice w stanie Luizjana i tam zamieszkała. Jakkolwiek nie była zamężna, adoptowała piętnastoletnią kuzynkę Liselottę Levy, którą nazywała swoim „największym błogosławieństwem”. Kuzynka przyjechała do niej z Europy w 1939 r., uciekając przed faszystowskim reżimem wraz z bratem Leonem, którym zaopiekował się brat Amelii - Julian ${ }^{156}$. Zmarła 1 stycznia 1966 r. Została pochowana na cmentarzu Beth Israel Cemetery, Meridian, w stanie Missisipi, obok swoich rodziców. Na jej grobie widnieje napis: „Amelia Greenwald, pielęgniarka, pielęgniarka wojskowa w trakcie I wojny światowej”157.

\section{Losy uczennic}

Po tragicznie zmarłej w 1936 r. Sabinie Schindlerównie dyrektorką Szkoły została Nina Lubowska, a wicedyrektorką Luba Blum-Bielicka. W 1939 r. zakupiono działkę przy ul. Dworskiej, obok Szpitala Starozakonnych, i planowano wybudować nowy gmach szkoły. W sierpniu Zarząd TPSP wydelegował Ninę Lubowską do Stanów Zjednoczonych, aby zdobyła fundusze na budowę „Szkoły Jej Marzeń” ${ }^{158}$. Tam też zastała ją wojna.

Uszkodzony w 1939 r. przez bombę gmach, w którym mieściła się Szkoła, odremontowano i 1 kwietnia 1940 r. przyjęto XXVII zespół uczennic (11 dziewcząt). Obowiązki dyrektorki podjęła dotychczaso-

${ }^{154}$ Departament Rolnictwa i Pracy Wsi (Department of Farm and Rural Work) przy Radzie Żydowskich Kobiet opiekował się pod względem organizacji, edukacji i spraw zdrowotnych ponad 2500 gospodarstwami (farmami) prowadzonymi przez Żydów w ośmiu stanach USA.

155 Pierwsza Szkoła Pielęgniarstwa na terenie Palestyny powstała w 1918 r. przy Szpitalu Rothschilda w Jerozolimie, dzięki Syjonistycznej Organizacji Kobiet Ameryki HADASSA utworzonej przez Henriettę Szold (The Women's Zionist Organization of America). Dziewczęta z pierwszego naboru ukończyły nauczanie w grudniu $1921 \mathrm{r}$. i zasiliły nowo powstające szpitale żydowskie na tych terenach.

156 Liselotta Levy-Weil mieszkała w domu swojej przybranej matki i prowadziła założony przez nią sklep do późnej starości. L.E. Turitz, dz. cyt., s. 292.

157 S. Mayer, Amelia Greenwald and Regina Kaplan..., dz. cyt., s. 89. Oryginalny napis: „Amelia Greenwald, Nurse, Army Nurse”. Corp, World War I”.

${ }^{158}$ L. Blum-Bielicka, dz. cyt., s. 68. 
wa jej zastępczyni Luba Blum-Bielicka. Po utworzeniu getta w listopadzie 1940 r. Szkoła, wraz z internatem, musiała przeprowadzić się na jego teren. Na nową siedzibę udało się pozyskać od Gminy Żydowskiej budynek Ubezpieczalni Społecznej u zbiegu ul. Mariańskiej 1 i Pańskiej 34. „Dom na Mariańskiej był duży, wygodny, można było zapomnieć w nim, że było się w getcie" 159 . Na parterze przy biurku dyżurowała zawsze jedna $\mathrm{z}$ uczennic. W korytarzu wisiał portret Florencji Nightingale. Obok wejścia po prawej stronie znajdował się gabinet dyrektorki i pokój, w którym mieszkała z dwojgiem dzieci. Była tam też sala wykładowa i sala ćwiczeń wyposażona w łóżko do nauki jego ścielenia, stół do badania pacjenta, szafki na leki oraz specjalną lalkę wielkości pięciomiesięcznego niemowlęcia do ćwiczeń manualnych. Pokoje uczennic znajdowały się na pierwszym i drugim piętrze. Stało tam od 10 do 12 łóżek ustawionych rzędem, nakrytych kocami, $\mathrm{z}$ czystą, białą pościelą. $W$ suterenie znajdowała się kuchnia $\mathrm{i}$ jadalnia. Codziennie rano 2 dyżurne uczennice schodziły na dół, by nakryć stoły białymi talerzami i filiżankami, na których znajdowała się dzienna porcja chleba. Porcje te $\mathrm{z}$ każdym tygodniem malały, zdarzało się, że uczennice kradły je dla swoich bliskich w getcie $^{160}$.

Uczennice, ubrane w charakterystyczne różowe sukienki z krochmalonymi kołnierzykami i krótkim rękawem, białe fartuchy na szelki, białe czapeczki i niebieskie peleryny, wyglądały ,jak różowe płatki kwiatów, może fiołków alpejskich, a w swojej jasności, czystości i pastelowej barwności sprawiały wrażenie istot nierealnych, zjaw przybyłych nie wiadomo skąd" ${ }^{161}$. Te peleryny długo chroniły uczennice. Przemierzały $w$ tych strojach getto do miejsc, gdzie odbywały praktyki: do szpitali, do Stacji Opieki nad Matką i Dzieckiem przy ul. Śliskiej oraz do punktów dla przesiedleńców. Zapisały piękną kartę $\mathrm{w}$ dramatycznej historii getta $\mathrm{z}$ racji bezgranicznego poświęcenia dla chorych ${ }^{162}$. Pomagały wszędzie, gdzie była potrzeba, idąc czasem jedynie z butelką wody lub słowami pocieszenia do oczekujących na wywiezienie na Umschlagplatzu. Początkowo uczennice były niejako nietykalne, ale wraz $\mathrm{z}$ rozpoczęciem deportacji także i one zaczęły trafiać na Umschlagplatz. Zwłaszcza po akcji wrześniowej dziewcząt nie było już zbyt wiele. Niektóre wyjechały na prowincję do rodziców,

159 A. Margolis-Edelman, dz. cyt., s. 34.

160 Tamże, s. 37.

161 A. Grupińska, Wywiad z Aliną Margolis-Edelman pt. Myśmy tam żyły jak w jakimś azylu, opublikowany w „Tygodniku Powszechnym” 9.05.2004, https://www.tygodnikpowszechny.pl/mysmy-tam-zyly-jak-w-jakims-azylu-125305 [dostęp: 22.03.2017].

${ }^{162}$ M. Ciesielska, Lekarze getta warszawskiego, Warszawa 2017, s. 230-231. 
inne poszły do fabryk i pracowały tam w charakterze sanitariuszek albo jako robotnice ${ }^{163}$. Dziewczęta, które pozostały w szpitalu, pracowały na dwie zmiany, dzienną i nocną. Zajmowały się głównie pielęgnacją obłożnie chorych ${ }^{164}$.

8 lipca 1942 r., a zatem na dwa tygodnie przed rozpoczęciem akcji likwidacyjnej getta, kurs ukończył XXVIII zespół uczennic, z którego wojnę przeżyła zaledwie jedna ${ }^{165}$.

Luba Blum-Bielicka pisała, że we wrześniu 1942 r. w szkole było jeszcze 19 uczennic, a Alina Margolis-Edelman, że po selekcji w tzw. kotle na Miłej pozostało ich 6, może 7. To możliwe, bo szkoła otrzymała zaledwie 20 „numerków życia”166. Nazajutrz po selekcji popełniła samobójstwo pielęgniarka Luba Aronson-Tenenbaum. Chciała przyznaną jej „kartę życia” przekazać swojej córce. Podarowała jej w ten sposób kilka miesięcy życia. Dwudziestodwuletnia Deda Tenenbaum zginęła kilka miesięcy później podczas ostatniej blokady szpitala na ul. Gęsiej ${ }^{167}$. Mirka Kleniec pracująca w szpitalu dziecięcym zginęła w Treblince, ale najpierw podała swojej matce śmiertelną dawkę morfiny ${ }^{168}$.

Luba Blum-Bielicka oraz pielęgniarki: Gurfinkiel-Glocer i Isserlis przetrwały tzw. akcję styczniową w 1943 r., chowając się w schronie zrobionym $\mathrm{w}$ piwnicy ${ }^{169}$. Akcji nie przeżyły m.in. pielęgniarki: Prużańska (z pierwszego zespołu), S. Fryd, Katz, Swierdzioł, Michelburg i Niemcówna ${ }^{170}$. Wówczas zginęła większość dziewcząt. Szczęście nie sprzyjało też innym. Marta Warhaftik, instruktorka pielęgniarstwa pediatrycznego, wyjechała w 1942 r. do swojej rodziny w Lublinie. Zginęła rozstrzelana na Majdanku jesienią 1943 r. w ramach tzw. akcji Dożynki ${ }^{171}$. Dora Blatman, instruktorka pielęgniarstwa społecznego, zajmująca się w getcie opieką nad dziećmi bezdomnymi, została spalona żywcem wraz ze swoją sześcioletnią córeczką w domu przy ul. Muranowskiej w trakcie powstania w getcie $^{172}$. Ze swoją córeczką

${ }^{163}$ H. Szereszewska, Krzyż i mezuza, Warszawa 1993, s. 131.

${ }^{164}$ L. Blum-Bielicka, dz. cyt., s. 74.

165 Tamże, s. 73.

166 Tamże, s. 75.

167 Relacja Judyty Braude, AYV 0.3/2360.

168 A. Blady-Szwajger, I więcej nic nie pamiętam, Warszawa 2010, s. 46, 122.

169 Relacja Sabiny Gurfinkiel-Glocer, Szpital na Czystem i ja, AYV 0.3/396.

${ }^{170}$ H. Szereszewska, dz. cyt., s. 215.

${ }^{171}$ L. Blum-Bielicka, dz. cyt., s. 69. Ostatni etap akcji „Reinhardt” dokonał się na terenie Majdanka 3 listopada 1943 r. w ramach tzw. akcji Dożynki (niem. Aktion Erntefest). W tym dniu funkcjonariusze Waffen SS, policji bezpieczeństwa oraz pułków policji 22 i 25 wymordowali ponad 18 tys. więźniów żydowskich ulokowanych na terenie obozu na Majdanku, jak również z innych obozów rozsianych po Lublinie.

${ }^{172}$ L. Blum-Bielicka, dz. cyt., s. 69. 
zginęła też Sonia Lifszyc, pielęgniarka Towarzystwa Przyjaciół Dzieci ${ }^{173}$. Luba Blum-Bielicka ocalała po tzw. stronie aryjskiej ${ }^{174}$. Po wojnie pisała, że spośród 400 byłych uczennic Szkoły Pielęgniarstwa na Czystem wojnę przeżyły zaledwie $42^{175}$.

\section{Bibliografia}

\section{I. Źródła archiwalne i ikonograficzne}

Archiwum Amerykańsko-Żydowskiego Połączonego Komitetu Rozdzielczego (American Jewish Joint Distribution Committee, dalej: JDC Archives) [tłum. dokumentów z języka angielskiego M. Ciesielska].

Zespół: Korespondencja Biura w Nowym Yorku 1921-1932 (Records of the New York Office 1921-1932) dalej: NY AR191232 i sygnatura dokumentu.

JDC Archives NY AR191232/4/25/3/0146. Memorandum Anny Bercowitz ze spotkania z H. Bridge, adresowane do Morrisa D. Waldmana, Departament Medyczno-Sanitarny AJJDC w Wiedniu, datowane na 17 stycznia $1922 \mathrm{r}$.

JDC Archives NY AR191232/4/25/3/078. List J. Goluba do B. Kahna datowany na 28 września $1923 \mathrm{r}$.

JDC Archives NY AR191232/4/25/3/0149. List B. Flexnera do Josephine Goldmark datowany na 10 kwietnia $1922 \mathrm{r}$.

JDC Archives NY AR191232/4/25/3/0158. Odpowiedź J. Goldmark na list B. Flexnera datowana na 15 kwietnia $1922 \mathrm{r}$.

JDC Archives NY AR191232/4/25/3/0178. List Williama J. Macka do Grace Allison datowany na 6 sierpnia $1922 \mathrm{r}$.

JDC Archives NY AR191232/4/25/3/0179. List G. Allison do W.J. Macka z dnia 15 września $1922 \mathrm{r}$.

JDC Archives NY AR191232/4/25/3/0217. List A. Greenwald do F.M. Warburga datowany 19 stycznia $1923 \mathrm{r}$.

JDC Archives NY AR191232/4/25/3/0218. Umowa datowana na 17 stycznia 1923 r. pomiędzy Amelią Greenwald a Bernardem Flexnerem.

JDC Archives NY AR191232/4/25/3/0222. Formularz i dokumenty zgłoszeniowe Ruth Hoffman, datowane na 2 lutego $1923 \mathrm{r}$.

${ }_{173}$ Archiwum Yad Vashem w Jerozolimie (AYV) 0.3/2360. Relacja Judyty Braude.

${ }^{174}$ Luba Blum-Bielicka zdeponowała dokumenty i pamiątki związane z działalnością szkoły w „bezpiecznych” miejscach. Niestety, uległy one zniszczeniu w czasie powstania warszawskiego w $1944 \mathrm{r}$.

${ }^{175}$ L. Blum-Bielicka, dz. cyt., s. 76. 
JDC Archives NY AR191232/4/25/3/0237. List A. Greenwald do Komitetu Spraw Medycznych AJJDC (B. Flexnera) datowany na 20 kwietnia $1923 \mathrm{r}$.

JDC Archives NY AR191232/4/25/3/0244. Orientacyjny plan i program Szkoły Pielęgniarstwa datowany na 2 maja $1922 \mathrm{r}$.

JDC Archives NY AR191232/4/25/3/0257. Wycinek prasowy z „Naszego Przeglądu" (bez daty).

JDC Archives NY AR191232/4/25/3/0258. List A. Greenwald do B. Flexnera datowany na 17 lipca $1923 \mathrm{r}$.

JDC Archives NY AR191232/4/25/3/0265. List A. Greenwald do B. Flexnera z dnia 22 sierpnia $1923 \mathrm{r}$.

JDC Archives NY AR191232/4/25/3/0273. Wycinek prasowy z „Kuriera Polskiego" (bez daty).

JDC Archives NY AR191232/4/25/3/0275. Wycinek prasowy z „Naszego Przeglądu" (bez daty).

JDC Archives NY AR191232/4/25/3/0258. List A. Greenwald do B. Flexnera, datowany na 17 lipca $1923 \mathrm{r}$.

JDC Archives NY AR191232/4/25/3/0265. List A. Greenwald do B. Flexnera datowany na 22 sierpnia $1923 \mathrm{r}$.

JDC Archives NY AR191232/4/25/3/0267. List A. Greenwald do Ruth Cohn datowany na 26 sierpnia $1923 \mathrm{r}$.

JDC Archives NY AR191232/4/25/3/0276. List J. Goluba do B. Kahna datowany na 28 sierpnia $1923 \mathrm{r}$.

JDC Archives NY AR191232/4/25/3/0278. List J. Goluba do B. Flexnera datowany na 7 listopada $1923 \mathrm{r}$.

JDC Archives NY AR191232/4/25/3/0280, Drugi raport A. Greenwald datowany na 1 czerwca $1923 \mathrm{r}$.

JDC Archives NY AR191232/4/25/3/0284. Orientacyjny plan i program Szkoły Pielęgniarstwa datowany na 2 maja $1922 \mathrm{r}$.

JDC Archives NY AR191232/4/25/3/0290. List A. Greenwald do B. Flexnera datowany na 4 listopada $1923 \mathrm{r}$.

JDC Archives NY AR191232/4/25/3/0306. List J. Goluba do B. Kahna datowany na 7 listopada $1923 \mathrm{r}$.

JDC Archives NY AR191232/4/25/3/0321. List A. Greenwald do B. Flexnera datowany na 23 listopada $1923 \mathrm{r}$.

JDC Archives NY AR191232/4/25/3/0322. List B. Flexnera do A. Greenwald datowany na 3 grudnia $1923 \mathrm{r}$.

JDC Archives NY AR191232/4/25/3/0324. List A. Greenwald do C. Noyes datowany na 13 grudnia $1923 \mathrm{r}$.

JDC Archives NY AR191232/4/25/3/0326. Telegram B. Flexnera do biura Jointu w Wiedniu datowany na 17 grudnia $1923 \mathrm{r}$. 
JDC Archives NY AR191232/4/25/3/0330. List A. Greenwald do B. Flexnera datowany na 27 grudnia $1923 \mathrm{r}$.

JDC Archives NY AR191232/4/25/3/0336. Projekt budżetu sporządzony przez TPSP na miesiąc maj $1922 \mathrm{r}$.

JDC Archives NY AR191232/4/25/3/0350. Raport dr. Z. Syrkin. Projekt budżetu w języku angielskim.

JDC Archives NY AR191232/4/25/3/0352. List Z. Syrkin-Binsztejnowej do dyrektora Departamentu Medyczno-Sanitarnego Jointu w Warszawie dr. Jacoba Goluba z dnia 30 czerwca 1922 r.

JDC Archives NY AR191232/4/25/3/0361. List dr Z. Syrkin-Binsztejnowej do S.M. Schmidt z dnia 10 lipca $1922 \mathrm{r}$.

JDC Archives NY AR191232/4/25/3/0363. Kosztorys prac budowlanych sporządzony 16 września 1922 r. przez inż. Stiefelmana.

JDC Archives NY AR191232/4/25/3/0369. List kuratora Szpitala Starozakonnych inż. Weisblata i lekarza naczelnego dr. Szwajcera do AJJDC z dnia 21 września $1922 \mathrm{r}$.

JDC Archives NY AR191232/4/25/3/0377. List Z. Syrkin-Binsztejnowej do dyrektora siedziby AJJDC w Warszawie Jacoba Goluba datowany na 27 września $1922 \mathrm{r}$.

JDC Archives NY AR191232/4/25/3/0392. List dr. Szwajcera do AJJDC datowany na 13 października $1922 \mathrm{r}$.

JDC Archives NY AR191232/4/25/3/0497, List B. Kahna do AJJDC $\mathrm{w}$ Nowym Yorku wraz $\mathrm{z}$ raportem A. Greenwald, datowany na 3 stycznia $1924 \mathrm{r}$.

JDC Archives NY AR191232/4/25/3/0499. List A. Greenwald do B. Kahna datowany na 26 grudnia $1923 \mathrm{r}$.

JDC Archives NY AR191232/4/25/3/0517. List A. Greenwald do inż. Weisblata z dnia 24 listopada $1923 \mathrm{r}$. [tłum. własne].

JDC Archives NY AR191232/4/25/3/0422. Statut Towarzystwa Popierania Szkoły Pielęgniarek przy Szpitalu Starozakonnych w Warszawie.

JDC Archives NY AR191232/4/25/3/0499. List A. Greenwald do B. Kahna datowany na 26 grudnia $1923 \mathrm{r}$.

JDC Archives NY AR191232/4/25/3/0517. List A. Greenwald do inż. Weisblata z dnia 24 listopada $1923 \mathrm{r}$.

JDC Archives NY AR191232/4/25/3/0527. Raport ze spotkania Zarządu Szkoły w dniu 25 listopada $1923 \mathrm{r}$.

JDC Archives NY AR191232/4/25/3/0554. Raport A. Greenwald datowany na 25 kwietnia $1924 \mathrm{r}$.

JDC Archives NY AR191232/4/25/3/0579. Memorandum J. Hymana wysłane do B. Flexnera, datowane na 12 sierpnia $1924 \mathrm{r}$. 
JDC Archives NY AR191232/4/25/3/0591. Raport A. Greenwald datowany na 1 września $1924 \mathrm{r}$.

JDC Archives NY AR191232/4/25/3/0600. List B. Kahna do B. Flexnera z dnia 25 września $1924 \mathrm{r}$.

JDC Archives NY AR191232/4/25/3/0618. List B. Flexnera do B. Kahna datowany na 28 listopada $1924 \mathrm{r}$.

JDC Archives NY AR191232/4/25/3/0622. Tłumaczenie na język angielski wycinka prasowego z nr 2790 „Naszego Przeglądu”.

JDC Archives NY AR191232/4/25/3/0624. Tłumaczenie artykułu z pisma „Hajnt” na język angielski (15 marca 1925 r.).

JDC Archives NY AR191232/4/25/3/0627. List B. Kahna do B. Flexnera datowany na 19 marca $1925 \mathrm{r}$.

JDC Archives NY AR191232/4/25/3/0635. Raport A. Greenwald dla AJJDC datowany na 5 marca $1925 \mathrm{r}$.

JDC Archives NY AR191232/4/25/3/0642. Listy B. Flexnera do B. Kahna i A. Greenwald oba datowane na 8 maja $1925 \mathrm{r}$.

JDC Archives NY AR191232/4/25/3/0665. Program uroczystości wręczenia dyplomów 11 października $1925 \mathrm{r}$. wraz z zaproszeniem dla B. Flexnera.

JDC Archives NY AR191232/4/25/3/0682. List A. Greenwald do B. Flexnera datowany na 26 lipca $1926 \mathrm{r}$.

JDC Archives NY AR191232/4/25/3/0688. Telegram A. Greenwald do B. Flexnera z dnia 1 grudnia $1926 \mathrm{r}$.

JDC Archives NY AR191232/4/25/3/0760. Telegram z biura AJJDC do United State Custom House w NY w sprawie przyjazdu Sabiny Schindler i Estery Szabad do Nowego Yorku.

JDC Archives NY AR191232/4/25/3/0772. Zapis rozmowy telefonicznej z dnia 8 października 1928 r. pomiędzy A. Greenwald a biurem Jointu.

JDC Archives NY AR/191232/4/25/0870. Maszynopis napisany przez

A. Greenwald (bez daty, bez tytułu).

Archiwum Żydowskiego Instytutu Historycznego (dalej AŻIH)

AŻIH, sygn. 301/5883, Relacja Sabiny Zenderman-Święcickiej.

Archiwum Działu Starej Książki Medycznej Głównej Biblioteki Lekarskiej

Teczki osobowe lekarzy - członków Izby Lekarskiej Warszawsko-Białostockiej w zbiorach Działu Starej Książki Medycznej Głównej Biblioteki Lekarskiej w Warszawie. Elektroniczne kopie teczek 
znajdują się w archiwum Sekcji Historycznej Okręgowej Izby Lekarskiej w Warszawie. Teczki osobowe lekarzy: Łazarza Zaksa oraz Marka Zaksa.

\section{Archiwum Yad Vashem (dalej: AYV) w Jerozolimie}

Relacja Sabiny Gurfinkiel-Glocer, Szpital na Czystem i ja, AYV 0.3/396.

\section{Biblioteka Narodowa (dalej: BN)}

„Pielęgniarka. Pismo wydane z inicjatywy słuchaczek szkoły z okazji ukończenia kursu nauk 1-go zespołu Szkoły Pielęgniarek przy szpitalu Starozakonnych w Warszawie w 1925 roku”, Warszawa 1926. BN, Sygn. 650.251.

\section{Materiały publikowane}

A. Książki i artykuły

Blady-Szwajger A., I więcej nic nie pamiętam, Warszawa 2010.

Blum-Bielicka L., Szkoła Pielęgniarstwa przy Szpitalu Starozakonnych $w$ Warszawie (1923-1943), „Biuletyn Żydowskiego Instytutu Historycznego" 1961, z. 4, nr 40.

Ciesielska M., Działalność Towarzystwa Ochrony Zdrowia Ludności Żydowskiej w Polsce (TOZ) ze szczególnym uwzględnieniem Kresów Wschodnich w okresie dwudziestolecia międzywojennego $w$ świetle dostępnych dokumentów, [w:] B. Urbanek (red.), Medycy polskiego pogranicza II Rzeczypospolitej 1918-1939, Wydawnictwo Instytutu Historii Nauki Polskiej Akademii Nauk, Warszawa 2018.

Ciesielska M., Lekarze getta warszawskiego, Warszawa 2017.

Chrzanowska H., O organizacji pielęgniarstwa w Polsce, „Pielęgniarka Polska” 1929, R. 1, nr 1.

Golden J.D., "Show that you are really alive": Sara-Zofia SyrkinBinsztejnowa's Emergency Medical Relief and Public Health Work in Early Interwar Poland and the Warsaw Ghetto, „Medizinhistorisches Journal” 2018, t. 53, z. 2.

Heller D.K., The Gendered Politics of Public Health: Jewish Nurses and the American Joint Distribution Committee in Interwar Poland, „Jewish History” 2018, nr 31.

Jezierska M.B., Warszawska Szkoła Pielegniarstwa w latach 1929-1939, [w:] Pochylone nad człowiekiem. Z dziejów Warszawskiej Szkoły Pielegniarstwa 1921-1945, Praca zbiorowa, Warszawa 1991. 
Margolis-Edelman A., Ala z „Elementarza”, Warszawa 2011.

Mayer S., Amelia Greenwald (1881-1966), [w:] V.L. Bullough, L. Sentz (red.), American Nursing: A Biographical Dictionary, t. 3, New York 2000.

Mayer S., Amelia Greenwald and Regina Kaplan: Jewish Nursing Pioneers, „Southern Jewish History” 1998, t. 1.

Mayer S., Amelia Greenwald: Pioneer in International Public Health, „Nursing and Health Care” 1994, t. 1, nr 15.

Mayer S., The Jewish Experience in Nursing in America: 1881 to 1955, 1996, Columbia University Teachers College.

Podgórska-Klawe Z., Szkoła Pielęgniarek na Czystem w Warszawie, [w:] B. Urbanek (red.), Zawód pielęgniarki na ziemiach polskich w XIX i XX wieku, Warszawa 2008, s. 218. Autorka artykułu powołuje się na prospekt: Szkoła Pielegniarstwa przy Szpitalu Starozakonnych w Warszawie 1923/1928. Ułożyła S. Schindlerówna, Warszawa 1928.

Szajkowski Z., „Reconstruction” vs. „Palliative Relief” In American Jewish Overseas Work (1919-1939), „Jewish Social Studies” 1970, t. 32 , nr 1.

Szereszewska H., Krzyż i mezuza, Warszawa 1993.

Turitz L.E., Amelia Greenwald: The Jewish Florence Nightingale, „American Jewish Archives” 1985, nr 37.

Zalashik R., Davidovitch N., The course of professionalization: Jewish nursing in Poland in the interwar period, „Science in Context” 2019, nr 32(1).

B. Prasa codzienna

„Chwila” 1930, nr 3917; 1937, nr 6628, 6557

„Jewish Daily Bulletin” 1927, t. 7, nr 681.

\section{Rozprawy doktorskie i prace magisterskie i licencjackie}

Kowalkowska I., Historia Szkoły Pielegniarstwa przy Szpitalu Starozakonnych na Czystem. Praca licencjacka wykonana pod kierunkiem prof. dr. hab. Marka Wichrowskiego w Zakładzie Historii Medycyny i Filozofii WUM, Warszawa 2009.

\section{Strony internetowe}

Grupińska A., Wywiad z Aliną Margolis-Edelman pt. Myśmy tam żyły jak w jakimś azylu, opublikowany w ,Tygodniku Powszechnym” 9.05.2004, https://www.tygodnikpowszechny.pl/mysmy-tam-zylyjak-w-jakims-azylu-125305. 
Pensacola Sanitarium Opens Its Doors, „Pensacola Journal” 1909, nr z 15 stycznia, s. 1. Tekst dostępny jest online: https://www.pensapedia.com/wiki/Pensacola_Sanitarium.

Rogow F., National Council of Jewish Women, https://jwa.org/encyclopedia/article/national-council-of-jewish-women.

Witkiewicz H., Warszawska Szkoła Pielegniarstwa, http://www.wmpp. org.pl/pl/szkoly-pielegniarskie/szko\%C5\%82a-warszawska.html. 